\title{
Ichnofabrics of shallow-marine mudstone, the result of changing environmental conditions: an example from the Middle Jurassic ore-bearing clay from southern Poland
}

\author{
Paulina Leonowicz ${ }^{1}$
}

Received: 28 January 2015 / Accepted: 16 April 2015 / Published online: 3 May 2015

(C) The Author(s) 2015. This article is published with open access at Springerlink.com

\begin{abstract}
Analysis of the trace fossil association and ichnofabrics from a Middle Jurassic shallow-marine mudstone, referred to as the Ore-Bearing Częstochowa Clay Formation, is used to reconstruct the seafloor conditions and identify the factors responsible for their changes. The trace fossil association contains Chondrites, Trichichnus, Palaeophycus, Planolites, Protovirgularia, ?Rosselia, Schaubcylindrichnus, Taenidium, cf. Tasselia, Thalassinoides, and five types of pyritized burrow. The association represents the distal expression of Cruziana ichnofacies, temporarily changing to a more proximal development. The ichnofacies suggests that the depositional site was located in the lower offshore to offshore-transition zone, periodically passing to the distal lower shoreface. Eight subtypes of the ichnofacies are recognized, reflecting variations in seafloor oxygenation, sedimentation rate, and benthic food content. The sequence of ichnofabrics $1 a-1 b-2 a-2 b$ reflects increasing oxygenation; ichnofabrics $4 \mathrm{a}, 4 \mathrm{~b}$, and 5 record high sedimentation rates, whereas ichnofabric 3 reflects sediment starvation. Vertical changes of ichnofabrics reflect major fluctuations in basin depth and distance from the shoreline, which partly correlate with previously recognized transgressive-regressive cycles. However, they do not record minor variations of the shoreline position.
\end{abstract}

Keywords Marine mudstone - Trace fossils . Ichnofabric · Ore-Bearing Częstochowa Clay Formation . Middle Jurassic · Silesian-Kraków Upland

Paulina Leonowicz

paulina.leonowicz@uw.edu.pl

1 Faculty of Geology, University of Warsaw, Żwirki i Wigury 93, 02-089 Warsaw, Poland

\section{Introduction}

Ichnofabric analysis is an important source of information in paleoecological and sedimentological studies of sedimentary rocks. Careful examination of ichnofabric may supply reliable information about the degree of oxygenation of the seafloor, the nature of the substrate, salinity, benthic food availability and sedimentation rate (cf. Wetzel 1991; Taylor et al. 2003). In the present study, the analysis of the trace fossil association and ichnofabrics of a shallowmarine mudstone was applied to interpret changes of depositional conditions linked to transgressions and regressions of the sea. It focuses on Middle Jurassic deposits, referred to as the Ore-Bearing Częstochowa Clay Formation, which are exposed in the Silesian-Kraków Upland in southern Poland (Fig. 1).

This fine-grained succession has been the subject of several geochemical, micropaleontological, and sedimentological studies (e.g., Merta and Drewniak 1998; Marynowski et al. 2007; Szczepanik et al. 2007; Zatoń et al. 2009, 2011; Gedl et al. 2012; Leonowicz 2012, 2013, 2015). Geochemical investigations, including analysis of biomarkers, $\mathrm{Th} / \mathrm{U}$ ratios, DOP and pyrite framboid distribution, indicated oxygenation of the bottom water and reducing conditions within the sediment (Marynowski et al. 2007; Szczepanik et al. 2007; Zatoń et al. 2009). Significant variations were not detected in the succession, suggesting that stable conditions prevailed on the seafloor. This, however, may have been the result of the relatively low resolution of the geochemical indices rather than actual paleoenvironment stability (Szczepanik et al. 2007; cf. Schieber 2003). Preliminary ichnological and micropaleontological studies of the selected 22-m-thick part of the succession showed that the bottom conditions changed with time even over a relatively short period of time (Smoleń 2006, 


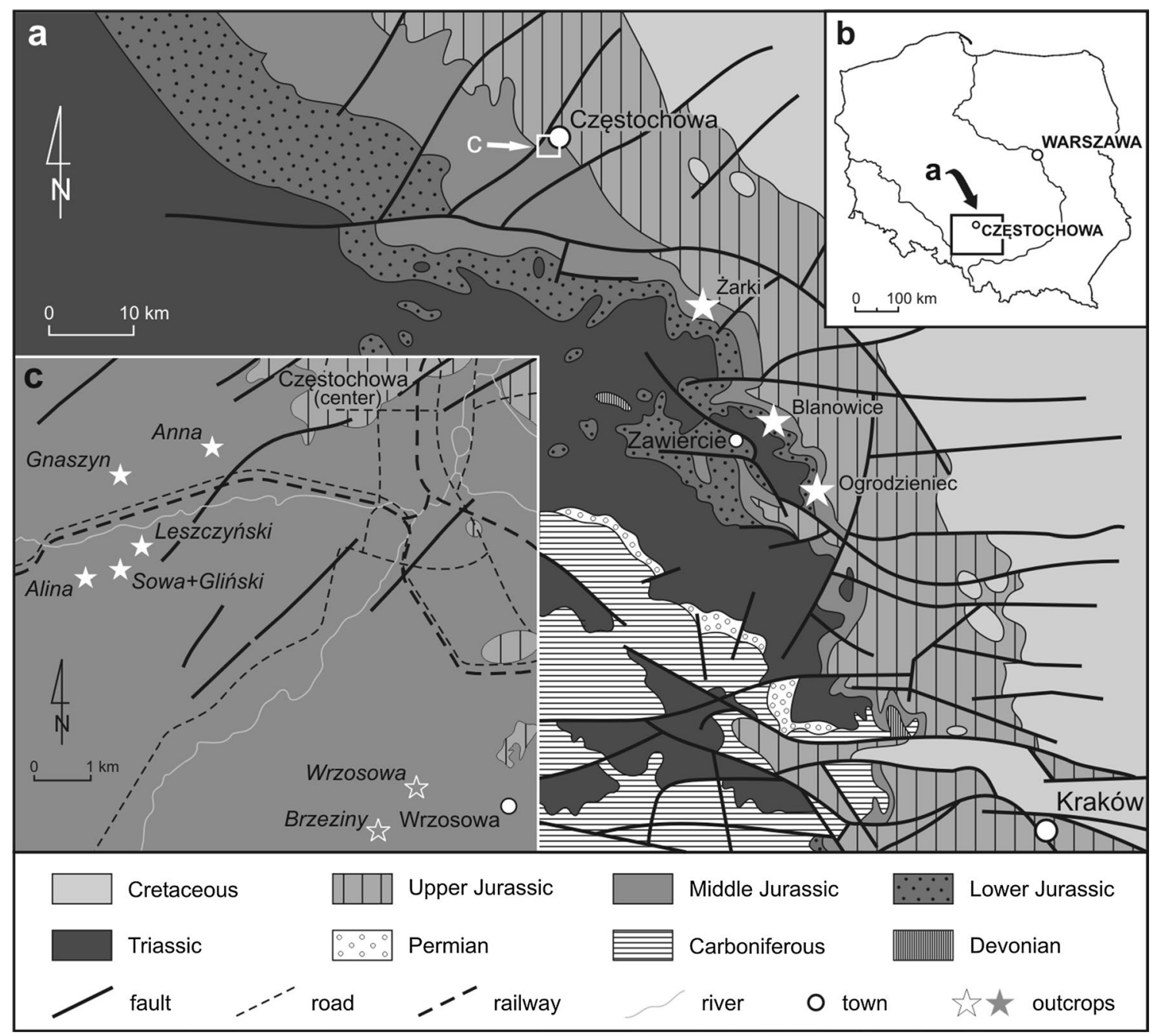

Fig. 1 a Geological map of the Silesian-Kraków Upland (after Dadlez et al. 2000, simplified) and the location of sections studied. Detailed location of exposures from Częstochowa is shown on $\mathbf{c} ; \mathbf{b}$ location of the area shown on a; $\mathbf{c}$ location of the clay-pit sec-

2012; Kaim and Sztajner 2012; Leonowicz 2012). Moreover, analysis of the trace fossil and benthic faunal associations from two facies varieties of the ore-bearing clay, exposed in different parts of the outcrop belt, indicated that the bottom conditions also varied laterally. The first facies, represented by laminated mudstone, was deposited in suboxic conditions, which periodically changed to dysoxic and rarely to anoxic (Leonowicz 2013). The second facies, consisting of bioturbated mudstone, accumulated in a permanently dysoxic environment prevailing within the sediment, under an oxygenated water column (Smoleń 2006, 2012; Kaim and Sztajner 2012; Leonowicz 2012). As shown by sedimentological analysis of microfabric, short-term changes in oxygen content most probably resulted from the activity of storm-generated bottom currents, redistributing sediment from shallower parts of the basin and simultaneously improving oxygenation of the seafloor (Leonowicz 2013). Longer-lasting fluctuations of tions on the geological sketch map of the western part of town of Częstochowa (after Lewandowski 1986, modified). White stars mark sections studied in detail and presented on Figs. 5 and 6; grey stars mark outcrops in which only observations of trace fossils were made

bottom-water conditions might be linked to changes in the position of the shoreline, as suggested in previous papers, based on variations of grain size, palynofacies, and sporomorph distribution (Gedl et al. 2012; Leonowicz 2015).

The aim of this study is to recognize variability of ichnofabrics in the succession of the Ore-Bearing Częstochowa Clay Formation to determine which environmental factors influenced the benthic community most significantly, and to check whether the variability of ichnofabrics corresponds to the cyclicity previously recognized by sedimentological and micropaleontological studies.

\section{Geological setting and lithology}

The Ore-Bearing Częstochowa Clay Formation, known also as ore-bearing clay, consists of dark grey, organic-rich, 
calcareous mudstone with several horizons of siderite and calcareous concretions and clayey siderite bands. Mudstone is enriched in organic matter; the TOC content ranges from 0.8 to $2.5 \%$ and this is predominantly of terrestrial origin (Marynowski et al. 2007; Szczepanik et al. 2007). The deposits which are strongly bioturbated contain a diverse benthic fauna, including bivalves, gastropods, brachiopods, scaphopods, foraminifers, and echinoderms (Gedl et al. 2012). The trace fossil association, reported in earlier papers, is of a low diversity and contains Chondrites, Trichichnus, Palaeophycus, Planolites, Thalassinoides, Taenidium, and indeterminate pyritized burrow fills (Gedl et al. 2006a, b, c; Leonowicz 2012). Laminated mudstone contains an impoverished benthic fauna, which includes mainly bivalves Bositra, local representatives of families Nuculidae and Nuculanidae, and small gastropods (Leonowicz 2013). The trace fossil association is also impoverished, containing Chondrites, Trichichnus, Palaeophycus, indeterminate pyritized burrows, and locally Protovirgularia (Leonowicz 2013).

Based on the common and well-preserved ammonite fauna, the age of ore-bearing clay was determined as the Upper Bajocian-Upper Bathonian (garantiana-discus zones: Kopik 1998; Matyja and Wierzbowski 2000, 2006b; Barski et al. 2004). It overlies Lower Bajocian Kościelisko Beds (Kopik 1997) and is overlain by condensed Callovian deposits (Fig. 2).

The ore-bearing clay was deposited in a marginal part of a shallow epicontinental sea, within the Polish Basin. This basin constituted the easternmost arm of an extensive system of epicontinental seas called the Central European Basin System (CEBS), which covered the area of Central Europe in the Mesozoic (Fig. 3). During the Jurassic, the Polish Basin was bordered from the east, northeast, and southwest by land (Dadlez 1989; Feldman-Olszewska 1997), whereas to the northwest and southeast it connected with CEBS and Tethys. Sedimentation in the Polish Basin began in the Aalenian, during a marine transgression, which most probably entered from the Tethyan Ocean through the East Carpathian Gate (Dayczak-Calikowska 1997). The oldest deposits occur only in the axial part of the basin, referred to as the Mid-Polish Trough (Fig. 4). As the transgression developed, the sea extended outside this zone, covering progressively still wider areas. In the Silesian-Kraków region, sedimentation started in the Early Bajocian (sauzei chron-Kopik 1998) and lasted, with a short break in the subfurcatum chron, until the end of the Middle Jurassic, continuing farther during the Late Jurassic (Matyja and Wierzbowski 2006a). This transgression was not uniform but consisted of several transgressive pulses, interrupted by short-lived regressions and periods of stillstand (e.g., Matyja and Wierzbowski 2006a; Pieńkowski et al. 2008). In the succession from central Poland,

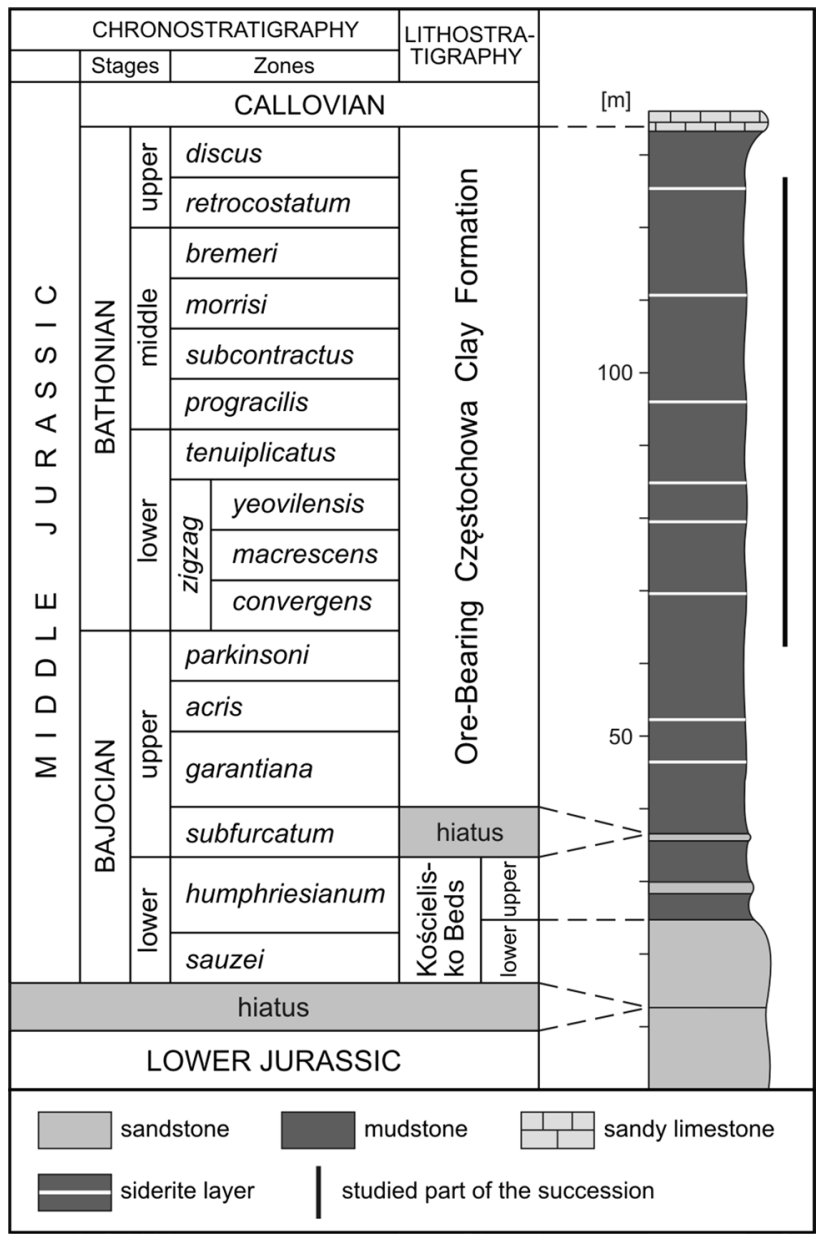

Fig. 2 Lithostratigraphy and biostratigraphy of the Middle Jurassic deposits from the Silesian-Kraków region (after Kopik 1998; Matyja and Wierzbowski 2000, 2006b; Barski et al. 2004) with an idealized lithological log

Pieńkowski et al. (2008) distinguished eight transgressiveregressive (T-R) cycles. In the section exposed in the middle part of the Silesian-Kraków region, Leonowicz (2015) recognized seven $\mathrm{T}-\mathrm{R}$ cycles, partly correlating with those from central Poland. Besides the fluctuations of the shoreline, deposition in the Polish Basin was also influenced by morphological differentiation of the seafloor into several swells and depressions, resulting from salt movements and syndepositional faults (Dadlez 1994; Feldman-Olszewska 1997; Pieńkowski et al. 2008). This differentiation is reflected by the lateral variability of thickness and facies type, which was recognized on a regional as well as local scale (Feldman-Olszewska 1997; Barski 1999).

The ore-bearing clay crops out in the Silesian-Kraków Upland in a narrow, NW-SE-oriented belt that wedges out south of Zawiercie (Fig. 1a). The succession reaches its maximum thickness of about $200 \mathrm{~m}$ in the central part of the outcrop belt, near Częstochowa (Kopik 1997). To 


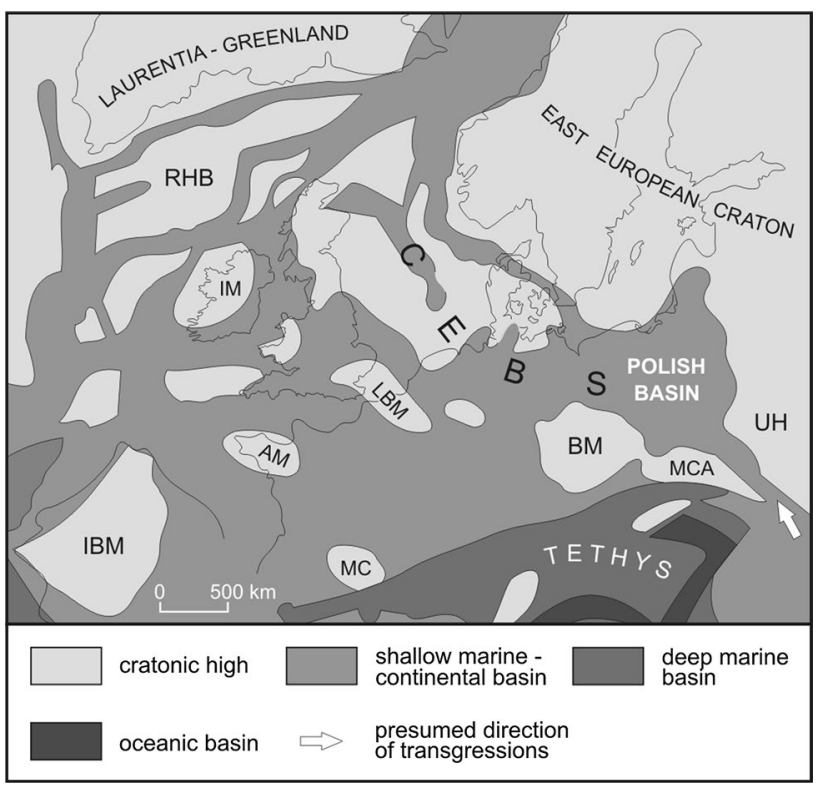

Fig. 3 Paleogeographical map of Europe in the Middle Jurassic (after Ziegler 1990, modified). AM Armorican Massif, BM Bohemian Massif, CEBS Central European Basin System, IBM Iberian Meseta, $I M$ Irish Massif, $L B M$ London-Brabant Massif, $M C$ Massif Central High, MCA Meta-Carpathian Arc, RHB Rockall-Hatton Bank, $U H$ Ukrainian High

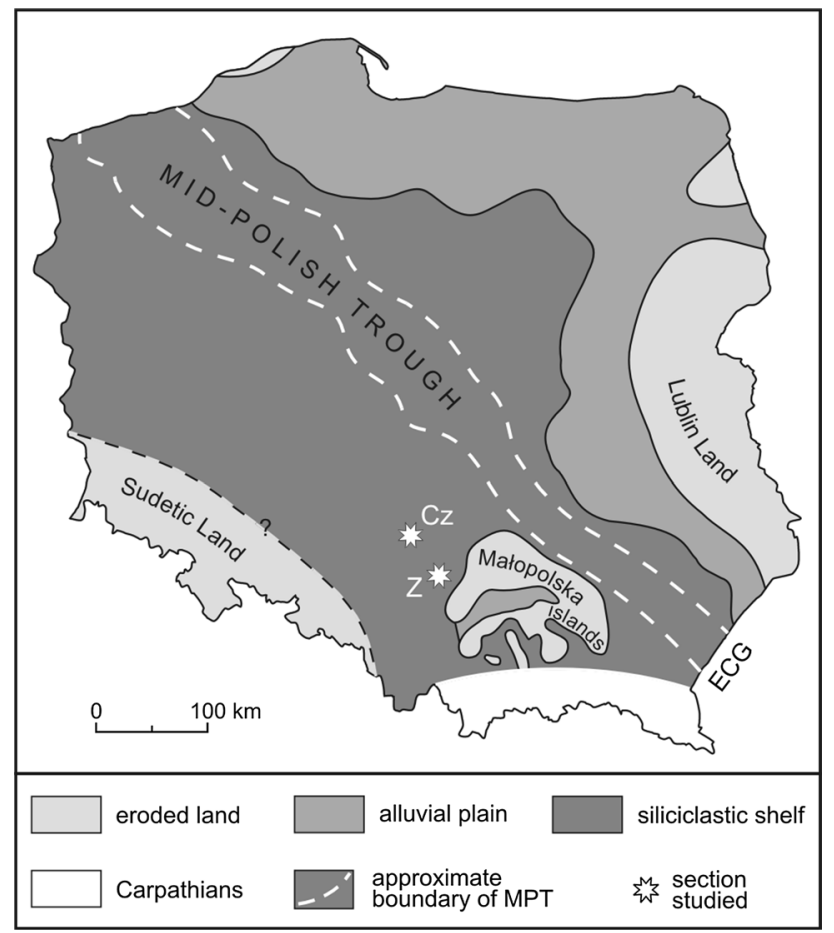

Fig. 4 Polish Basin in the Middle Bathonian (bremeri chron, after Feldman-Olszewska 1998, modified) and the location of sections studied. ECG East Carpathian Gate, $C z$ Częstochowa, $Z$ Zawiercie the south, the thickness decreases, and near Zawiercie it is about $60 \mathrm{~m}$ (Kopik 1998). The decrease in thickness is accompanied by a reduction of the older parts of the succession that results from its onlap on to older Mesozoic rocks. The studied succession is situated in the middle and southern parts of the outcrop belt, between Częstochowa and Ogrodzieniec (Fig. 1a), where dark mudstone is exposed in several clay pits. This succession spans the interval from the Upper Bajocian parkinsoni zone to the Upper Bathonian retrocostatum zone (Fig. 2; Matyja and Wierzbowski 2003, 2006b; Zatoń 2007; Zatoń et al. 2011, 2012).

\section{Materials and methods}

Ichnological observations were undertaken in ten clay pits located in Częstochowa, Żarki, Blanowice, and Ogrodzieniec (Fig. 1a, c). Eight selected sections were examined centimeter by centimeter and two types of bioturbation structure were determined: trace fossils and biodeformational structures (cf. Wetzel 2008). They were observed on fresh surfaces, in sections perpendicular, parallel and oblique to the bedding. Additionally, relative abundance, dimensions, cross-cutting relationships of trace fossils, and the total intensity of bioturbation were recorded. The intensity of bioturbation was estimated using the ichnofabric index (i.i.) scheme of Droser and Bottjer (1986).

\section{Results and interpretations}

Dark mudstone of the Ore-Bearing Częstochowa Clay Formation contains bioturbation in the entire succession studied, even in the intervals with preserved primary lamination (Figs. 5, 6). There is variation, however, in bioturbation intensity and diversity of the trace fossil association. Ichnofabric index i.i. ranges from $2(0-10 \%)$ in laminated mudstone to $5(60-100 \%)$ in strongly bioturbated zones. Diversity of the trace fossil association varies from low to moderate, involving ten ichnogenera and a few indeterminate forms. Their descriptions and interpretations are presented in Table 1. The trace fossils never occur all together. Four ichnofossils: Chondrites, Trichichnus, pyritized burrows type 1 and Palaeophycus are common throughout the entire succession. Other ichnogenera, i.e., Planolites, Protovirgularia, ?Rosselia, Schaubcylindrichnus, Taenidium, Tasselia-like structures, Thalassinoides, and other types of pyritized burrow occur only in some intervals (Figs. 5, 6). They form five types of tiered ichnofabric with varieties reflecting degree of the association completeness. From cross-cutting relationships, at least four 


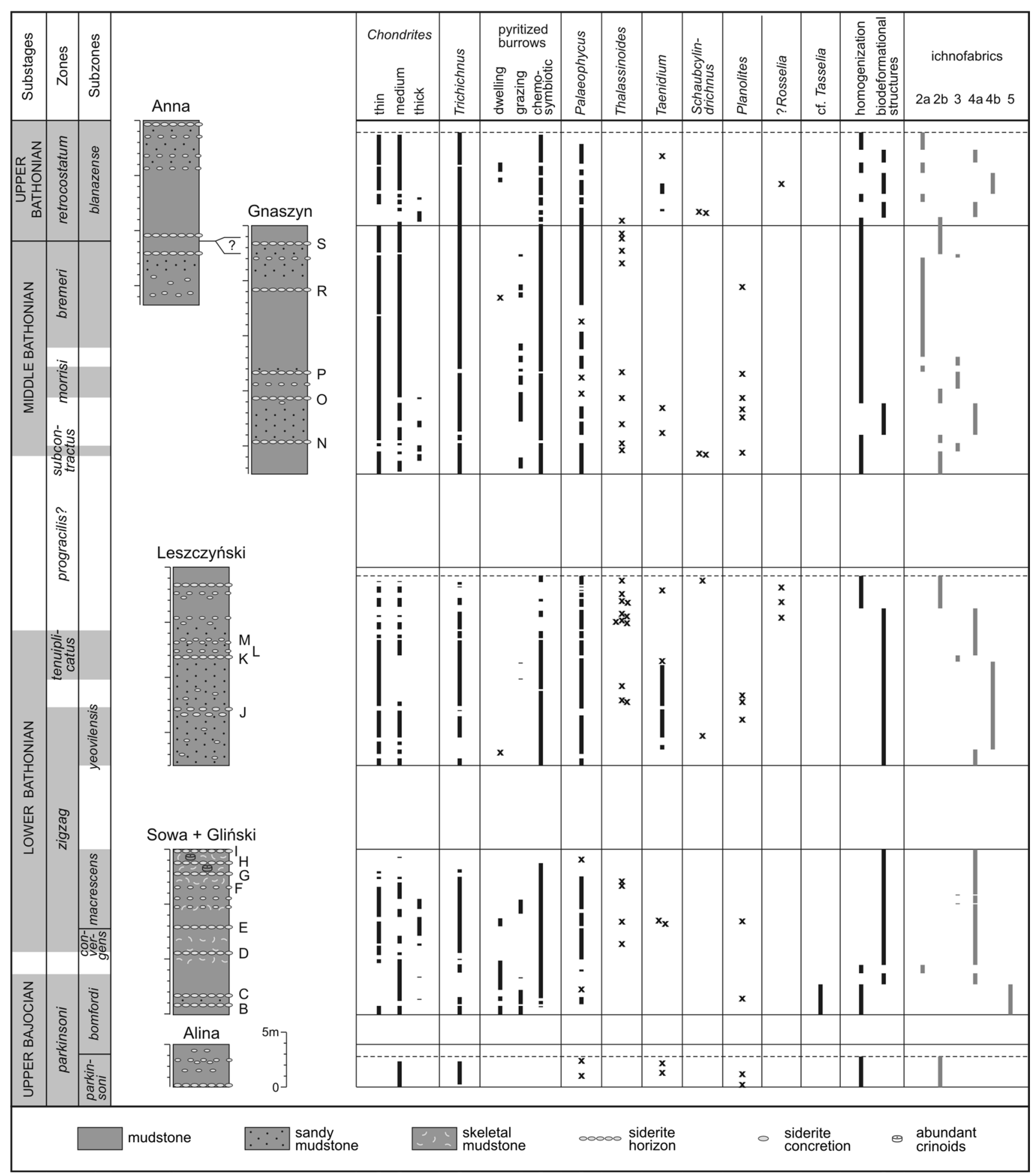

Fig. 5 Distribution of trace fossils and ichnofabrics in the succession of ore-bearing clay from Częstochowa. Thick lines mark intervals with common occurrences of particular bioturbation structures, $x$ single occurrences. Biostratigraphy after Matyja and Wierzbowski (2000, 2003, 2006b); dated intervals are marked in grey tiers can be distinguished in the most diverse ichnofabric (cf. Leonowicz 2012). The shallowest one comprises a bioturbated background with indeterminate biodeformational structures. The second one is represented by different grazing, feeding, crawling, and dwelling structures. A still deeper tier consists of Chondrites and the deepest one is 

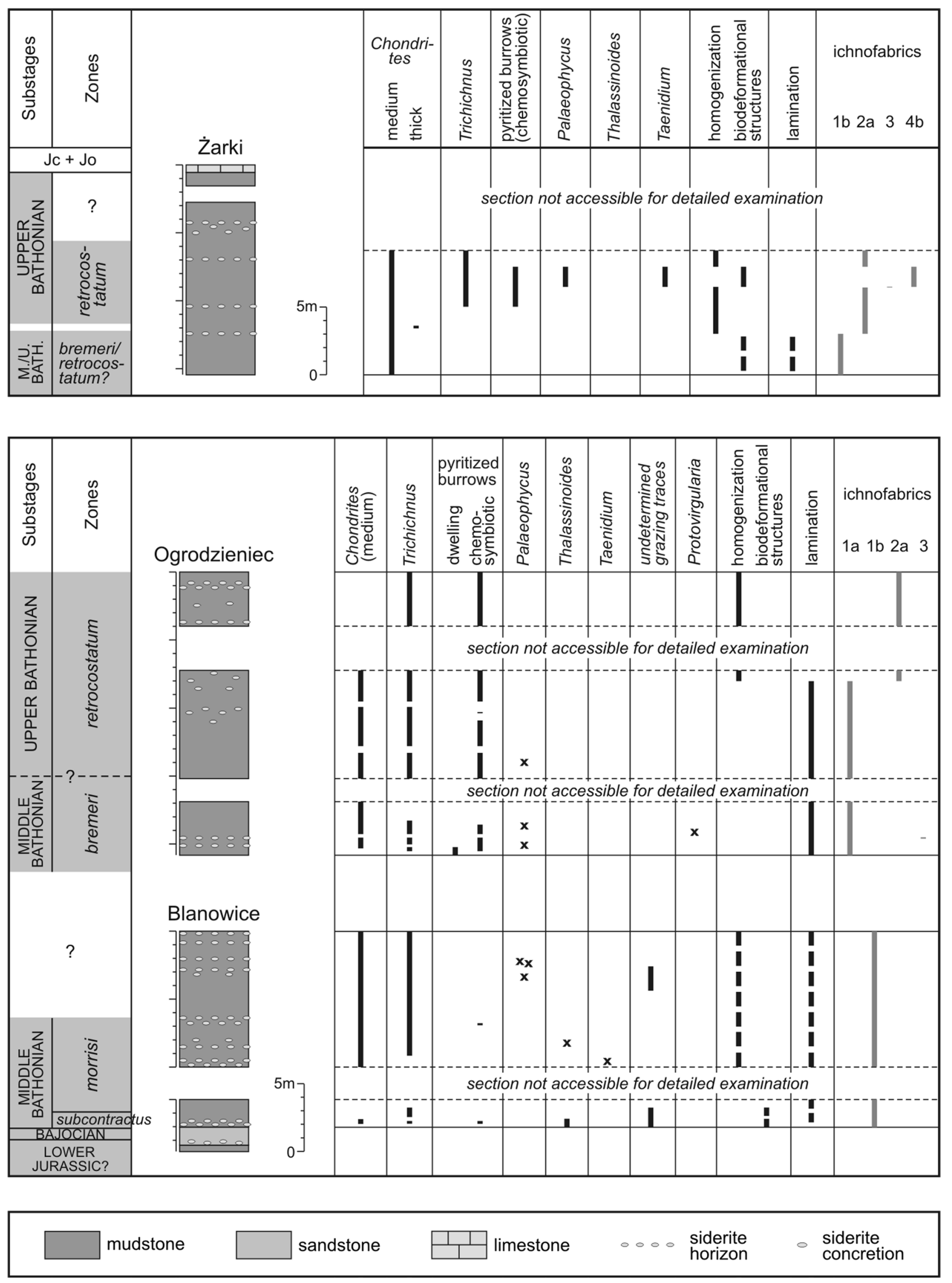

Fig. 6 Distribution of trace fossils and ichnofabrics in the succession of ore-bearing clay from Żarki and Zawiercie area. For explanation of symbols, see Fig. 5 caption. Biostratigraphy after Zatoń (2007) and Zatoń et al. (2011,2012); dated intervals are marked in grey 


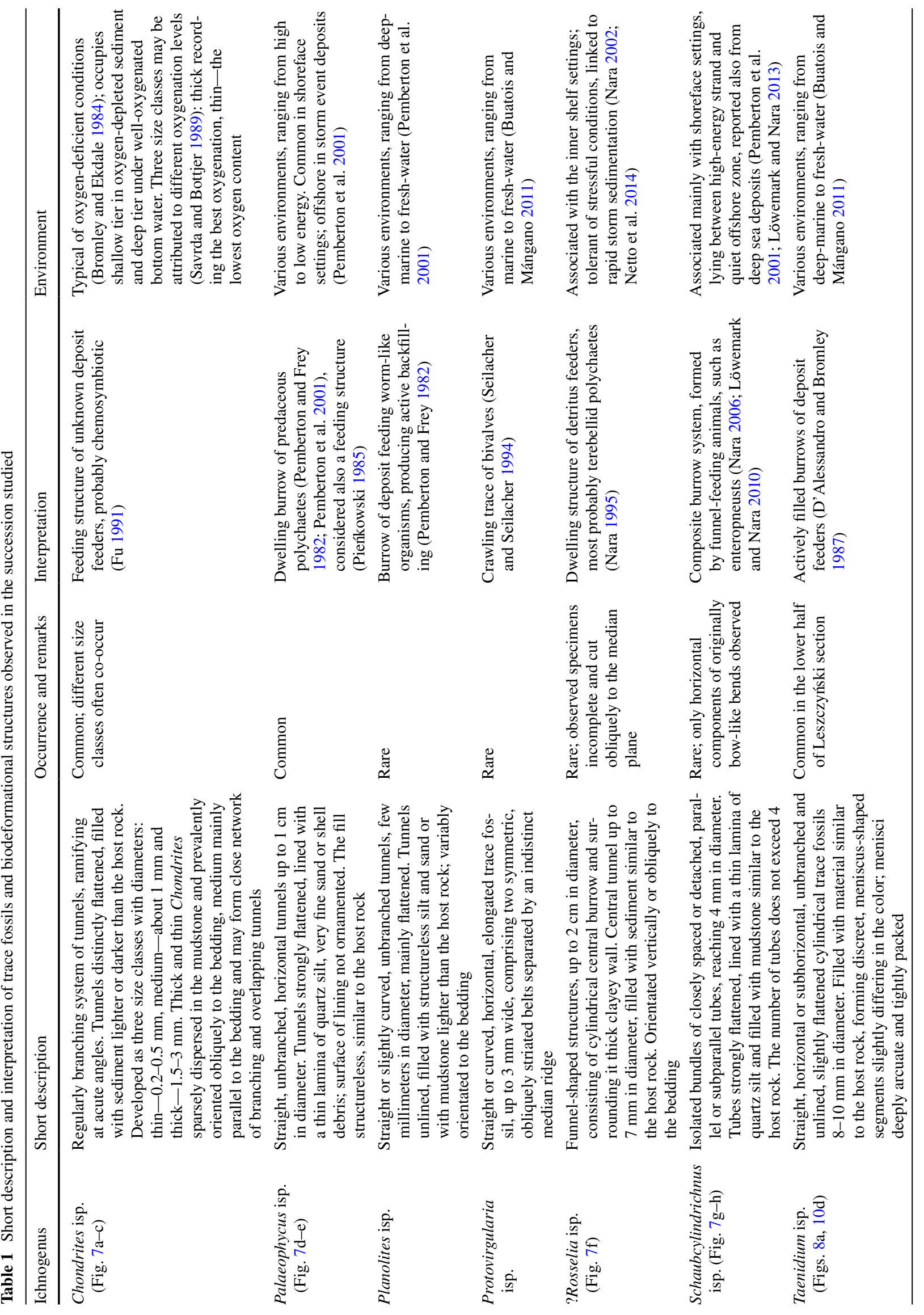




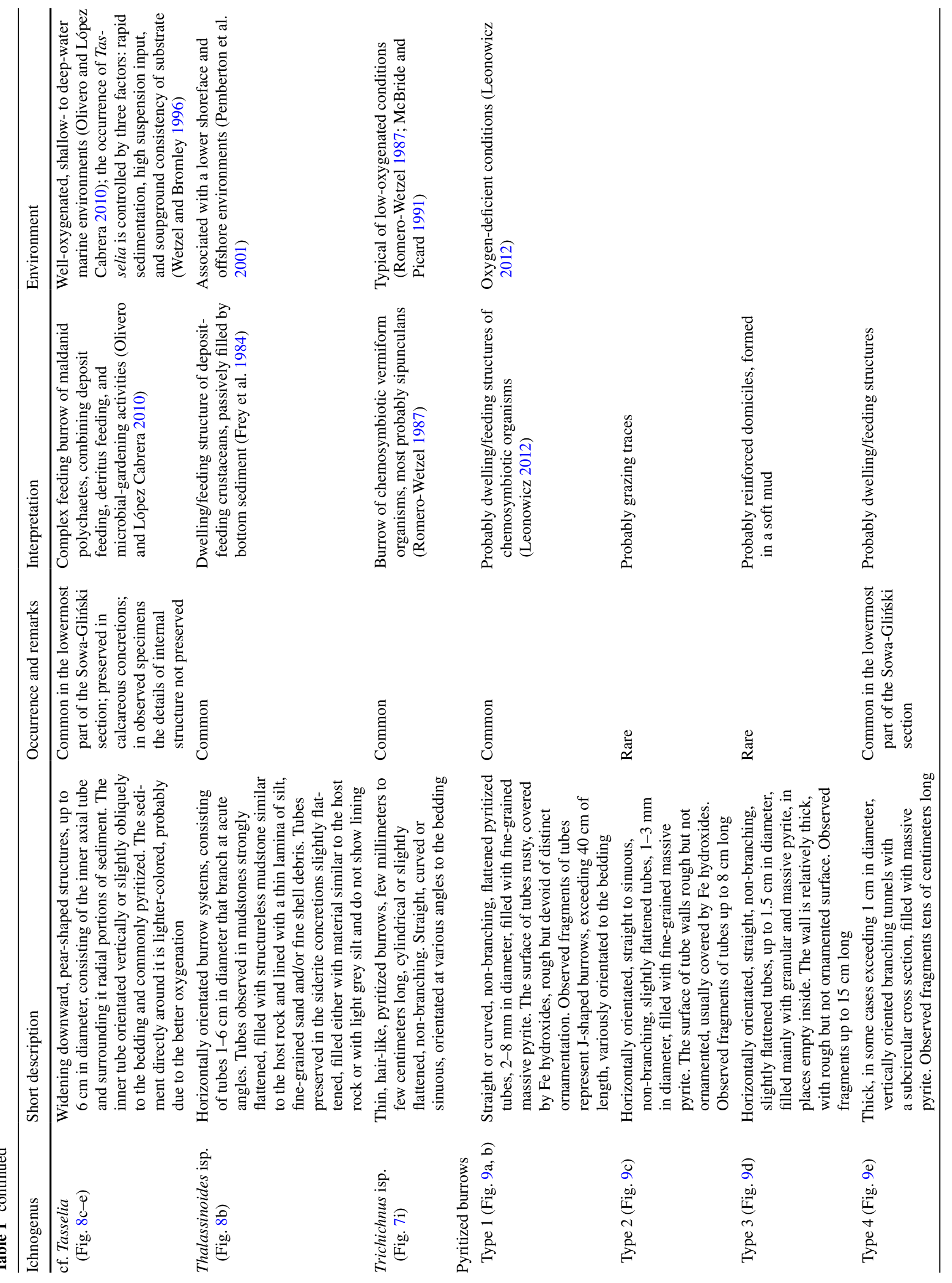


occupied by Trichichnus and pyritized burrows type 1 . Most probably, the second, most diverse tier, can be divided into another two. Taking into account the typical trend in vertical stacking of infaunal communities (Bromley and Ekdale 1986), sediment processors are expected to occupy a deeper level than dwelling animals; however, crosscutting of these burrows was not observed in the deposits studied and the relationships between them remain unknown. Similarly, the co-occurring three size classes of Chondrites, referring to diameter (Table 1), may belong to different tiers. Studies of modern and ancient deposits have shown that a decrease in oxygen availability leads to a decrease in the size of burrows of a similar type (Savrda et al. 1984; Wetzel 1991; Martin 2004). According to this, size differences of Chondrites from the ore-bearing clay most likely reflect various levels of oxygenation, existing at different depths of penetration, although the cross-cutting relationships between them could not be deduced.

Taking into account bioturbation intensity, composition of the trace fossil association and the type of biodeformational structures (mottles, homogenization, cryptobioturbation), eight ichnofabric variants have been distinguished.

\section{Ichnofabric characteristics}

Ichnofabric 1a: occurring in parallel laminated mudstone (Fig. 10a, b)

Description this ichnofabric is characterized by sparse to low bioturbation intensity (i.i. = 2-3) and low diversity of the trace fossil association. Biodeformational structures are represented by cryptobioturbation, which is common but discernible only in thin-section. It occupies the shallowest tier of ichnofabric. The middle tier is represented by Palaeophycus, Protovirgularia and probably pyritized burrows type 3, a deeper one by Chondrites and the deepest one by Trichichnus and pyritized burrows type 1. Trace fossils are scattered and discreet; they cut laminae but do not obliterate them and are visible mainly on horizontal parting planes, except Trichichnus and Chondrites, which are commonly oriented obliquely. Trichichnus and pyritized burrows occur throughout the section, similarly as cryptobioturbation, whereas Chondrites, Palaeophycus and local Protovirgularia were observed mainly within silt-sand laminae. This type of ichnofabric was observed in the Ogrodzieniec clay-pit (Fig. 6) and was already studied in detail by Leonowicz (2013).

Interpretation the common occurrence of cryptobioturbation and the scarcity of trace fossils, most of which were produced by animals adapted to low-oxygenated conditions, indicate that laminated mudstone records deposition in a restricted, oxygen-deficient environment. Deposits showing only cryptobioturbation, Trichichnus and pyritized 

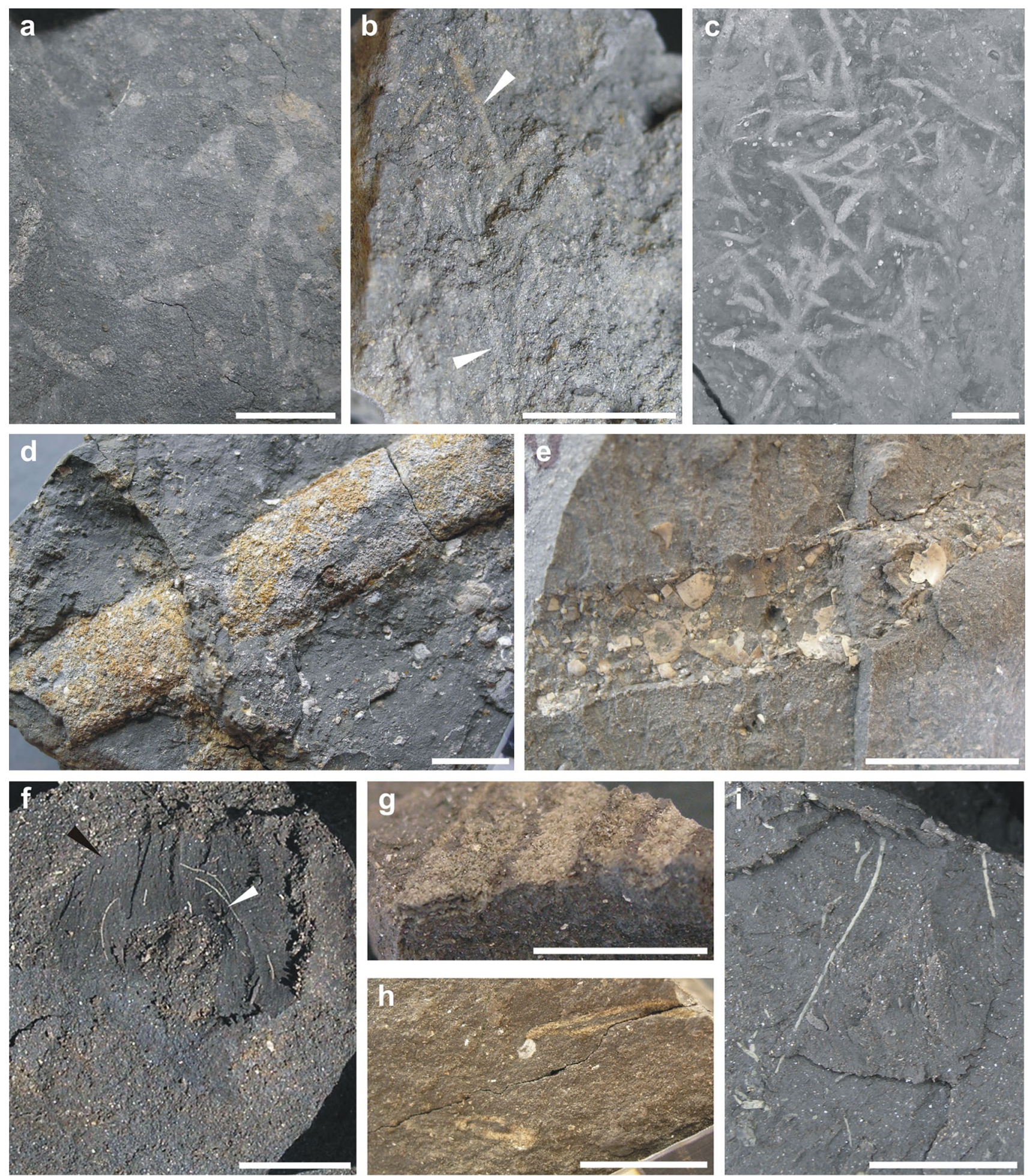

Fig. 7 Trace fossils from ore-bearing clay. Three size classes of Chondrites isp., according to diameter: thick (a), thin (b), and the net of medium-sized tunnels (c), sections oblique to the bedding; Palaeophycus isp.: lined with a thin lamina of silt (d) and coarse shell debris (e), views on parting planes; $\mathbf{f}$ ?Rosselia isp., seen on the edge of mudstone piece. On the upper surface, thick clayey wall (black arrow) and the central burrow, filled with matrix similar to the host rock, are visible; the wall is reworked by horizontal Trichichnus (white arrow). In the vertical section, clayey wall wedges out downward; Schaubcylindrichnus isp.: g bundle of four closely spaced tubes, view on parting plane, $\mathbf{h}$ two detached tubes, vertical cross section; i Trichichnus, section oblique to the bedding. Scale bar is $1 \mathrm{~cm}$; a, d Sowa-Gliński, b Leszczyński, c, g, h, i Gnaszyn, e Brzeziny, f Anna (photo $\mathbf{c}$ by A. Uchman) 

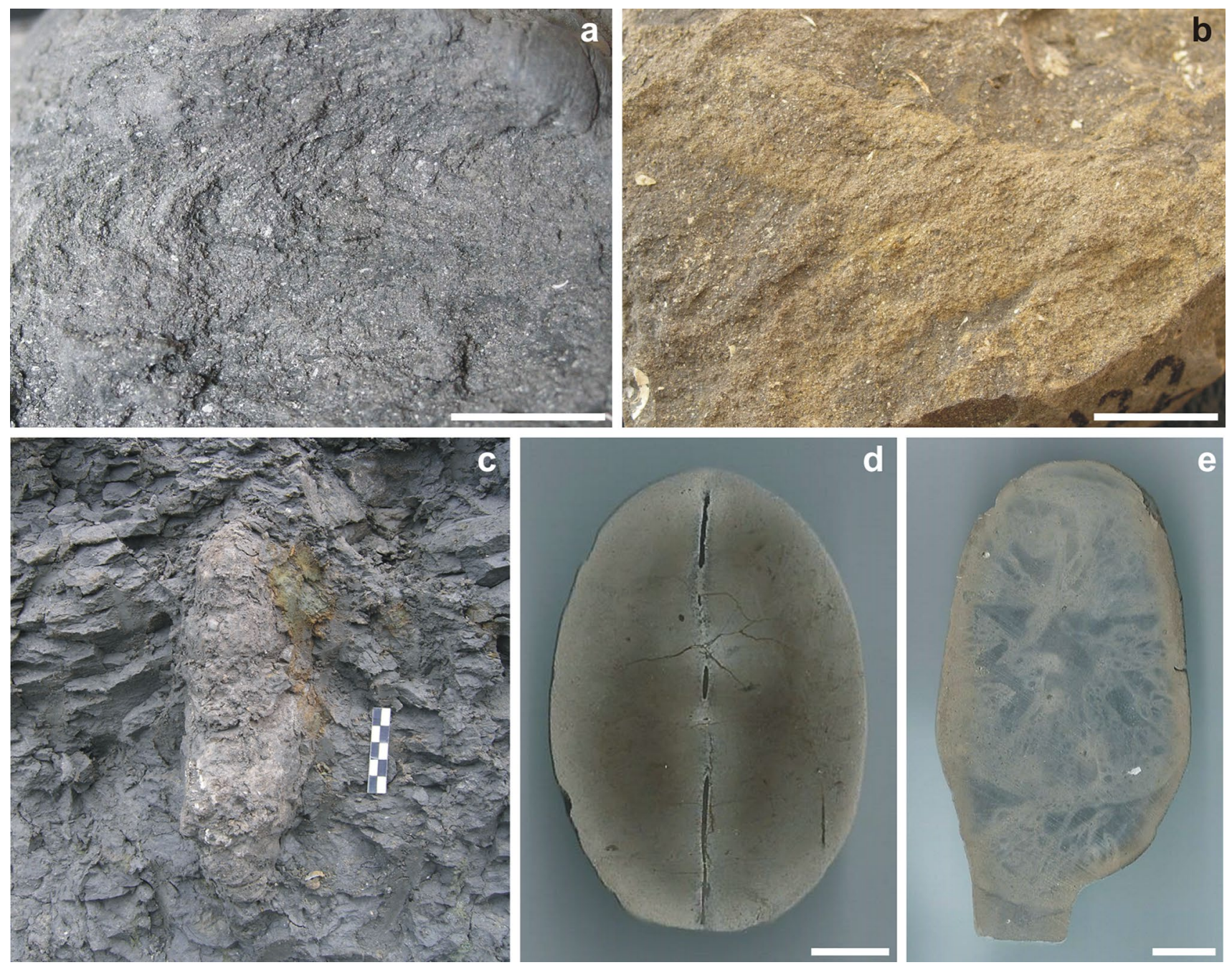

Fig. 8 Trace fossils from ore-bearing clay. a Taenidium, vertical section; b Thalassinoides, view on parting plane; cf. Tasselia: c vertically oriented calcareous concretion with cf. Tasselia inside, d pyritized inner tube surrounded by reworked lighter material, verti-

burrows represent quasi-anaerobic biofacies (sensu: Savrda and Bottjer 1991), developed in most severe conditions (Leonowicz 2013). Intermittent, short reoxygenation episodes, linked to deposition of silt-sand laminae, resulted in temporal improvement of oxygenation, establishment of dysoxic conditions and development of a more diverse, tiered ichnofabric.

\section{Ichnofabric 1b: alternating laminated and bioturbated intervals (Fig. 10c)}

Description this ichnofabric consists of alternating, $2-10$-cm-thick intervals of parallel laminated and strongly bioturbated mudstone. Laminated deposits reveal features typical of ichnofabric 1a. Bioturbated intervals are either homogenized or show various biodeformational structures, cal polished section, e radial elements spreading out from the central tube, vertical section. Scale bar in $\mathbf{a}, \mathbf{b}, \mathbf{d}, \mathbf{e}$ is $1 \mathrm{~cm}$, in $\mathbf{c}$ is in centimeters; a Leszczyński, b Wrzosowa, c-e Sowa-Gliński

both clearly visible in the outcrop. Bioturbation intensity changes from sparse to low (i.i. $=2-3$ ) in laminated intervals to moderate to high (i.i. $=4-5)$ in bioturbated ones. The diversity of the trace fossil association is generally low. Besides Trichichnus and pyritized burrows type 1, occupying the deepest tier, deep-tier Chondrites and representatives of the middle tier: Palaeophycus, local Thalassinoides and Taenidium also occur. This ichnofabric was observed in the Blanowice and Żarki exposures (Fig. 6). In the second locality, the interval revealing ichnofabric $1 \mathrm{~b}$ passes upwards into strongly bioturbated deposits.

Interpretation the occurrence of strongly bioturbated intervals within a laminated sequence (Blanowice section) suggests that they record episodes of oxygenation improvement. In this case, the ichnofabric $1 \mathrm{~b}$ records deposition in an oxygen-deficient environment, similarly for ichnofabric 

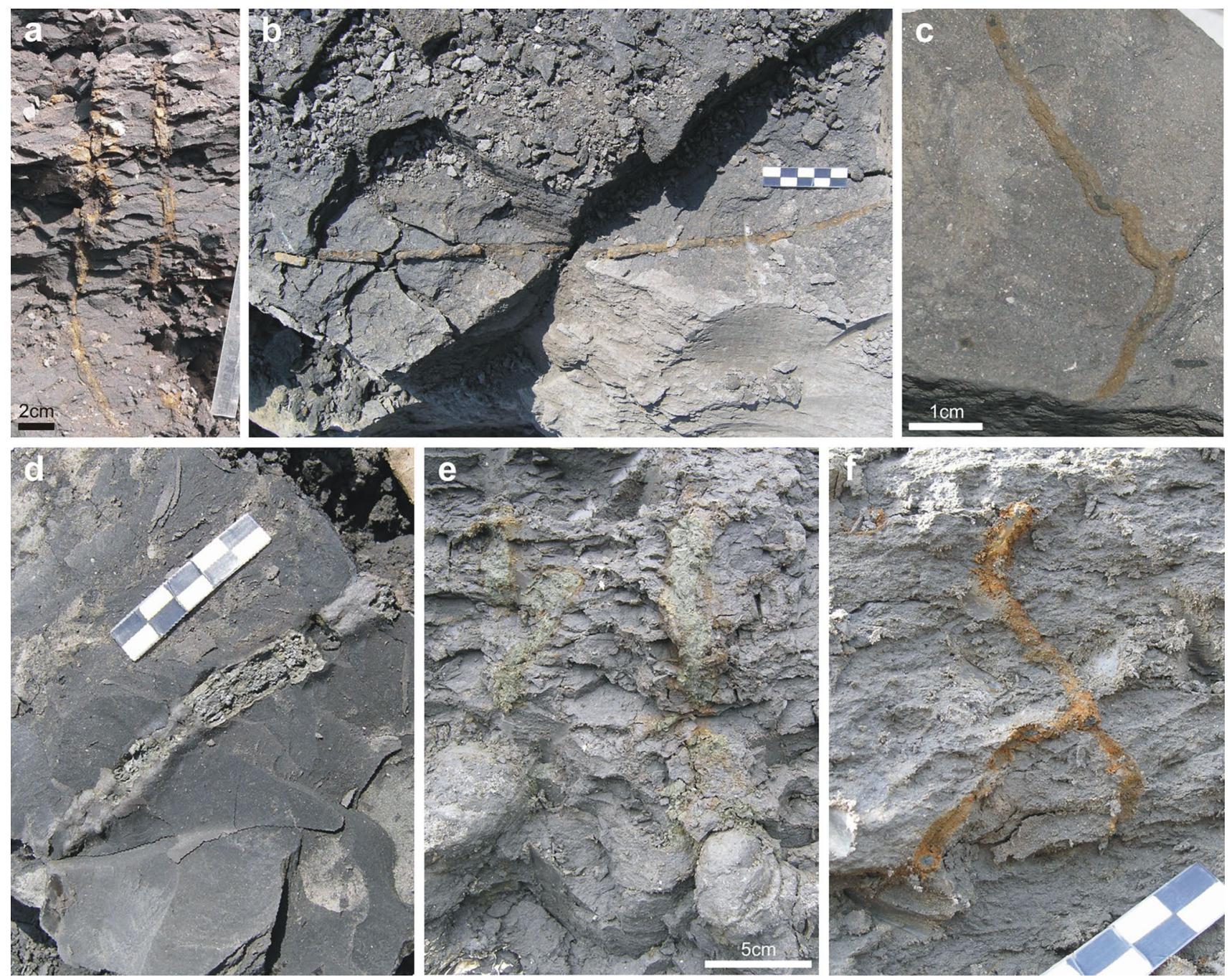

Fig. 9 Trace fossils from ore-bearing clay. Pyritized burrows type 1: vertical (a) and horizontal (b) fragments of J-shaped tunnels; c pyritized burrow type 2, view on parting plane; d pyritized burrow type 3 , view on parting plane; e pyritized burrows type 4 , vertical sec-

variant 1a, but with longer-lasting periods of reoxygenation. If the interval with laminated-bioturbated couplets occurs within bioturbated deposits (Żarki section), it is likely that this ichnofabric resulted from recurrent episodic sedimentation of relatively thick portions of mud in an oxygenated environment. In such a case, a high sedimentation rate would have caused only the upper part of sediment to be reworked by burrowing animals, with the lower part remaining undisturbed (cf. a "smothered bottom" in Brett 1983).

Ichnofabric 2a: impoverished trace fossil association in a homogenized background

Description this ichnofabric consists of dispersed, uncommon trace fossils occurring in the homogenized tion; f pyritized burrow type 5, vertical section; scale bar in $\mathbf{b}, \mathbf{d}, \mathbf{f}$ is in centimeters; a, b Gnaszyn, c, f Leszczyński, d Ogrodzieniec, e Sowa-Gliński (photo a by A. Uchman)

background sediment. Bioturbation intensity is moderate to high (i.i. $=4-5$ ) and diversity of the trace fossil association is low. The association consists of common Trichichnus and pyritized burrows type 1 representing the deepest tier, deep-tier Chondrites and middle-tier Palaeophycus and pyritized burrows type 2 . In moderately bioturbated deposits, background sediment shows an indistinct parallel fabric, consisting of vague parallel stripes of a different color. This feature probably resulted from the incomplete bioturbation of a primary horizontal lamination (cf. Leonowicz 2013). This type of ichnofabric occurs in the middle parts of the sections at Gnaszyn and Żarki and in the uppermost parts of the sections at Anna and Ogrodzieniec (Figs. 5, 6).

Interpretation bioturbation of the whole sediment indicates that oxygenation of the seafloor was better than in 

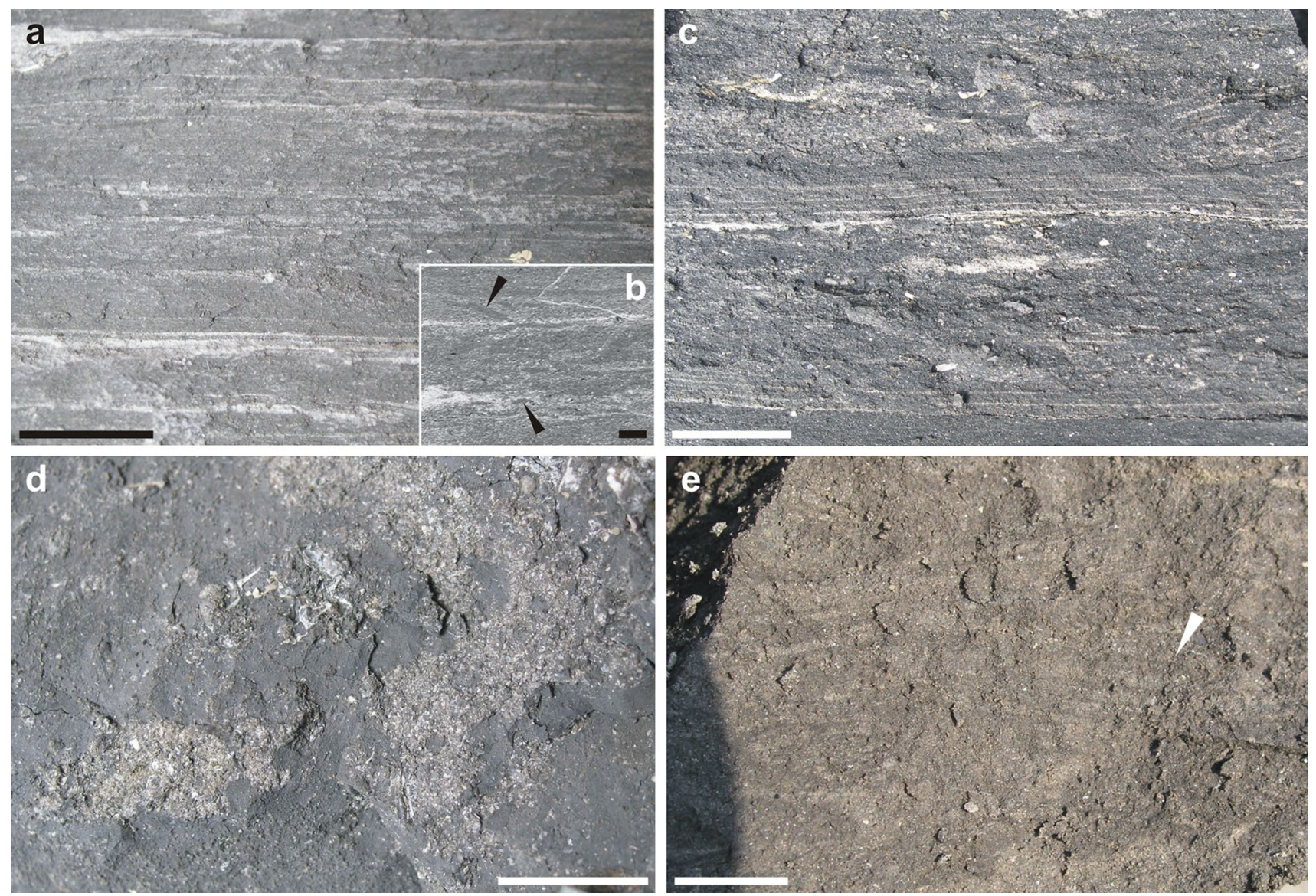

Fig. 10 Ichnofabrics from ore-bearing clay. Ichnofabric 1a: a laminated mudstones, vertical section; b discreet micro-burrows (arrows) responsible for cryptobioturbation, thin section view; c ichnofabric 1b: laminated mudstones alternate with bioturbated intervals showing irregular biodeformational structures, vertical section; d ichno-

the case of ichnofabrics $1 \mathrm{a}$ and $1 \mathrm{~b}$. However, the low diversity of the trace fossil association, dominated by deep-tier ichnogenera typical of oxygen-depleted environments, points to restricted dysoxic conditions (cf. Leonowicz 2012). Most probably mudstone was deposited in predominantly dysoxic conditions, in which only animals adapted to a low oxygen content could survive. Oxygenation of the seafloor occasionally improved during reoxygenation episodes, enabling the producers of Palaeophycus to inhabit the seafloor.

\section{Ichnofabric $2 b$ : diverse trace fossil association in homogenized background}

Description this ichnofabric consists of relatively common trace fossils occurring in the homogenized background sediment. Bioturbation intensity is moderate to high (i.i. $=4-5$ ) and the diversity of the trace fossil association is moderate. The most common ichnofossils are Chondrites fabric type $4 \mathrm{a}$, dominated by irregular biodeformational structures filled with fine shell debris, view on parting plane; e ichnofabric type $4 \mathrm{~b}$, dominated by biodeformational structures and Taenidium (arrow), vertical section. Scale bar in $\mathbf{a}, \mathbf{c}-\mathbf{e}$ is $1 \mathrm{~cm}$, in $\mathbf{b}$ is $1 \mathrm{~mm}$; $\mathbf{a}$, b Ogrodzieniec, c Żarki, d Sowa-Gliński, d Leszczyński

representing the deep tier, Trichichnus and pyritized burrows type 1 occupying the deepest tier and Palaeophycus, which belongs to the middle tier. Other representatives of the middle tier, including Thalassinoides, pyritized burrows type 2, 3 and 5, Planolites, ?Rosselia, Schaubcylindrichnus and Taenidium are rare. In some intervals, thick Chondrites appear. This type of ichnofabric occurs in the Alina section, in the upper part of Leszczyński section, in the lower and uppermost part of the Gnaszyn section and in the Anna section (Fig. 5).

Interpretation the relatively diverse trace fossil association indicates that oxygenation of the bottom sediment was still better than in previous ichnofabrics. However, the full set of ichnofossils does not occur throughout deposits showing this ichnofabric and some ichnogenera such as Thalassinoides, Planolites, ?Rosselia, Schaubcylindrichnus, and Taenidium occur as single specimens scattered in the succession. It suggests that the bottom conditions changed with time and only during periods of the best 
oxygenation did a more diverse association develop. When the oxygenation decreased some trace fossils disappeared and the association became impoverished.

\section{Ichnofabric 3: dense Chondrites network}

Description this ichnofabric is dominated by abundant, horizontally or subhorizontally oriented Chondrites (Fig. 7c), which causes strong bioturbation of the sediment. Bioturbation intensity is moderate to high (i.i. = 4-5) and the diversity of the trace fossil association is low. Besides Chondrites representing the deep tier, it comprises Trichichnus and pyritized burrows type 1 occupying the deepest tier and sparse Palaeophycus, pyritized burrows type 2 and some indeterminate grazing traces from the middle tier. Chondrites is represented by two size classes referring to diameter-medium and thin. It forms the close network, which conforms to a relict horizontal lamination, enhancing the parallel fabric of the rock. This type of ichnofabric occurs as 10-140-cm-thick intercalations within other ichnofabric types and partially coincides with intervals with common ammonite occurrences. It was observed in the Sowa-Gliński, Leszczyński, Gnaszyn, Żarki and Ogrodzieniec exposures (Figs. 5, 6).

Interpretation the strong bioturbation by one ichnogenus (Chondrites), produced by deeply burrowing animals, suggests that this kind of ichnofabric may record periods of decreased sedimentation rate. Limited sediment delivery led to the persistent reworking of sediment within a particular depth range, resulting in the obliteration of ichnofossils from shallower tiers (Bromley 1990). This interpretation is reinforced by the common occurrence of ammonites, interpreted as a result of sediment condensation (Leonowicz 2015), observed in the intervals with a dense Chondrites network.

\section{Ichnofabric 4a: dominated by biodeformational structures (Fig. 10d)}

Description the most characteristic components of this ichnofabric are well discernible biodeformational structures. The intensity of bioturbation is moderate to high (i.i. $=4-5$ ) and the diversity of the trace fossil association is moderate, but distinct ichnofossils are scattered and not common. The association includes Trichichnus and pyritized burrows type 1 from the deepest tier, Chondrites representing the deep tier as well as Palaeophycus, Thalassinoides, pyritized burrows type 2, 3 and 4, rare Planolites, Taenidium and local ?Rosselia occupying the middle tier. Chondrites is represented by three size classes referring to diameter and the thick variety is quite common. In mudstone rich in shell debris, biodeformational structures are usually developed as irregular, elongated accumulations of disarticulated and fragmented shells of bivalves and small gastropods, oriented obliquely to the bedding. Skeletal mudstone, occurring in the uppermost part of the SowaGliński section, contains an impoverished association of trace fossils that includes mainly thin pyritized burrows type 1, local Trichichnus and Chondrites. The ichnofabric 4a occurs in the Sowa-Gliński section, upper part of the Leszczyński section, in the lower part of the Gnaszyn section and in the middle part of the Anna section (Fig. 5).

Interpretation moderate diversity of the trace fossil association points to a relatively well oxygenated environment that is additionally confirmed by the appearance of thick Chondrites, especially common in this variant of ichnofabric. However, similar to the case of ichnofabric $2 b$, the full set of ichnofossils occurs only in some intervals that may reflect either a fluctuation of oxygenation or patchy distribution of the fauna. Patchiness is a well-known feature of benthic communities from shallow-marine as well as deepmarine settings (e.g., Tufail et al. 1989; Cosson et al. 1997; McIlroy 2007), which results from various physical and biotic processes, including varying hydrodynamic regimes, pulsed input of food, small-scale bottom topography (bedforms and biogenically produced mounds), and trophic specialization of competing organisms (Buatois and Mángano 2011). In time-averaged assemblages, this heterogeneity is not visible, but if sedimentation rate is high it may lead to incomplete reworking of sediment by animals from particular tiers, which have not enough time to pass through the whole area (Wetzel 1991). The increased sedimentation rate in ichnofabric $4 \mathrm{a}$ is supported by the domination of biodeformational structures, which result from burrowing of deposit and detritus feeding animals in the uppermost, soupy part of sediment. The high benthic food content, which usually accompanies a high input of sediment, causes that behavioral specialization becomes unnecessary and well-defined trace fossils, recording various feeding strategies are rare (Wetzel and Uchman 1998). Further impoverishment of the trace fossil association in skeletal mudstone could have resulted from a still higher sedimentation rate and unfavorable substrate composition, in which coarse-grained shell debris prevailed.

\section{Ichnofabric 4b: dominated by Taenidium (Fig. 10e)}

Description the most characteristic components of this ichnofabric are Taenidium and biodeformational structures. Bioturbation intensity is high (i.i. = 5) and the diversity of trace fossil association is moderate; however, all ichnofossils beside Taenidium are uncommon and scattered. The background sediment is intensively mottled. Beside Taenidium, which is the main component of the middle tier, trace fossil association contains Chondrites (deep tier), Trichichnus and pyritized burrows type 1 (the deepest tier) as well as Palaeophycus, Planolites, Thalassinoides, pyritized burrows types 2 and 4, local Schaubcylindrichnus 
and ?Rosselia (middle tier). In some intervals, a thick variety of Chondrites appears. Thin Chondrites commonly occurs within elliptical or irregularly shaped, indeterminate burrows, together forming composite burrows (sensu: Chamberlain 1975). This type of ichnofabric occurs in the lower half of Leszczyński section and in the middle parts of sections at Anna and Żarki (Figs. 5, 6).

Interpretation the similarity between ichnofabrics $4 \mathrm{a}$ and $4 \mathrm{~b}$ indicates that both of them reflect similar conditions, i.e., good oxygenation and relatively high sedimentation rate. However, the common occurrence of Taenidium in ichnofabric $4 \mathrm{~b}$ suggests that the sediment input and benthic food content were probably lower than in the case of ichnofabric dominated only by biodeformational structures. Observations of modern benthic communities from shallow-water environments showed that the first response to the rapid input of phytodetritus was the appearance of surface deposit feeders and suspension feeders, whereas more diverse feeding strategies developed only after a few weeks (Quijón et al. 2008). In the case of ichnofabric $4 b$, organic matter was firstly exploited by subsurface trophic generalists, burrowing in the mixed layer. When the easy accessible organic particles became exhausted, the remaining nutrients dispersed in homogenized sediment were acquired by more specialized, deeper-burrowing deposit feeders, responsible for the production of Taenidium.

\section{Ichnofabric 5: with cf. Tasselia}

Description the most characteristic components of this ichnofabric are thick pyritized burrows type 4 and Tasselia-like structures, preserved in spindle-shaped calcareous concretions. Intensity of bioturbation is moderate to high (i.i. $=4-5)$ and the diversity of the trace fossil association is low. Besides the ichnofossils mentioned above, occupying the middle tier, it contains Chondrites (deep tier), Trichichnus (the deepest tier), Palaeophycus and locally Planolites (middle tier). Background sediment is homogenized or mottled. This ichnofabric variety occurs in the lower part of Sowa-Gliński section (Fig. 5).

Interpretation the occurrence of Tasselia-like structures points to a well-oxygenated environment. Low diversity of the trace fossil association may have resulted from stressful conditions, linked to rapid sedimentation and high suspension input that are conducive to Tasselia (Wetzel and Bromley 1996).

\section{Discussion}

\section{Sedimentary environment}

The muddy substrate and the predominance of feeding, grazing and dwelling traces of deposit feeders, accompanied by structures formed by detritus feeders, chemosymbionts and carnivores, indicates that the trace fossil association from the ore-bearing clay represents the Cruziana ichnofacies (e.g., Pemberton et al. 2001). Low to moderate diversity of the ichnofossil suite, an organicrich substrate and the common occurrence of trace fossils characteristic of low-oxygen conditions point to the distal expression of this ichnofacies, which combines features of ichnofacies Cruziana and Zoophycos. It is characteristic of fully marine conditions, including lower offshore, prodelta, and shelf transition (MacEachern et al. 2007). In the case of the Polish Basin, which was in the Middle Jurassic a semi-enclosed epicontinental sea, the designation "shelf" is not exactly appropriate; thus the location of the depositional site shall be defined as a lower offshore to offshoretransition, i.e., below and above the storm wave base. Such a definition does not imply a deep-water location, as effective storm wave base in epicontinental seas usually does not exceed $30 \pm 10 \mathrm{~m}$ (Immenhauser 2009). The ichnofabrics dominated by Taenidium and biodeformational structures (ichnofabrics $4 \mathrm{a}$ and $4 \mathrm{~b}$ ) may reflect deposition in more proximal settings, in the distal lower shoreface near fair weather wave base (MacEachern et al. 2007).

The morphology of trace fossils points to variable substrate consistency, reflecting increasing compaction and dewatering of sediment that resulted from progressive burial (cf. Bromley and Ekdale 1986). Irregular shapes and indistinct boundaries of biodeformational structures, constituting the shallowest ichnofabric tier, indicate that they were produced by animals "swimming" through the soupy substrate (Bromley 1990). The thin linings of the open burrows from the middle tier (e.g., Palaeophycus, Thalassinoides and Schaubcylindrichnus) point to the stability of cohesive muddy substrate, whereas the strong flattening of their horizontal and subhorizontal components indicates high porosity and low consolidation of the sediment. These trace fossils as well as actively filled burrows of deposit feeders easily moving through the unconsolidated mud (Taenidium) were emplaced in the substrate of a softground type (cf. Buatois and Mángano 2011). Trace fossils from deep tiers (Chondrites, Trichichnus, pyritized burrows type 1), might be produced in a semi-consolidated sediment, representing a firmground (cf. Schieber 2003; Buatois and Mángano 2011). This interpretation does not concern cases where these ichnofossils constitute the only components of ichnofabric, suggesting their shallow emplacement in the poorly oxygenated substrate. In fact, Chondrites has often strongly flattened tunnels, pointing to its relatively shallow formation in a soft mud.

The low to moderate diversity of the trace fossil association indicates that the sedimentary environment of the ore-bearing clay was generally not favorable for a diverse macrobenthic tracemaker community. The predominance 
of ichnofossils, produced by animals adapted to oxygendeficient conditions (Chondrites, Trichichnus and pyritized burrows type 1), which maintain the connection with bottom water, and simultaneous limited occurrence (except ichnofabrics $4 \mathrm{a}$ and $4 \mathrm{~b}$ ) of other ichnogenera, suggest that the main factor restricting development of the benthic community was oxygenation of bottom sediment. The gradation in the succession from laminated to strongly bioturbated deposits reflects changes in seafloor oxygenation, controlling the distribution of ichnofabrics (cf. Taylor et al. 2003). According to the oxygen-related trace fossil model proposed by Savrda and Bottjer (1989) and confirmed by later studies (e.g., Martin 2004), decreasing oxygenation of the seafloor results in a decrease in the trace fossil size, diversity of the trace fossil association, and bioturbation depth, the latter leading to the disappearance of higher tiers. Applying this assumption, the sequence of ichnofabrics $1 \mathrm{a}-1 \mathrm{~b}-2 \mathrm{a}-2 \mathrm{~b}$ may be interpreted as a record of increasing oxygenation of the seafloor. The most severe conditions are recorded by quasi-anaerobic biofacies, characteristic of laminated mudstone (ichnofabric 1a). Reoxygenation episodes in this case were short and led to temporal establishment of dysoxic conditions, reflected by a more diverse but still strongly impoverished trace fossil association and low intensity of bioturbation. In ichnofabric $1 \mathrm{~b}$, periods of oxygenation improvement lasted longer, resulting in the formation of bioturbated intervals up to $10 \mathrm{~cm}$ thick. Ichnofabric 2a records permanent dysoxic conditions prevailing within the sediment that are reflected by the trace fossil association of a low diversity, occurring within a homogenized background sediment. The best but still not fully oxygenated conditions are recorded by ichnofabric $2 b$, characterized by a moderately diverse trace fossil association and bioturbated background sediment. The dispersed occurrence of middle tier trace fossils in ichnofabrics $2 \mathrm{a}$ and $2 \mathrm{~b}$ suggests that also in these cases the oxygenation of the bottom sediment was not constant and reached the highest level during recurrent episodes of oxygenation improvement. These episodes were most probably linked to the activity of bottom currents, generated during storms that ventilated the seafloor. The occurrence of such currents was previously indicated by sedimentological analysis of the ore-bearing clay that revealed several types of storm deposit (Leonowicz 2013, 2015). They include thin and thick silt-sand laminae, bedding plane accumulations of shell debris, bundles of silt-sand laminae, small sandy lenses, and up to 6-cm-thick silt-, sand- and shell-debrisrich levels. The internal structures of these accumulations (e.g., laminae with sharp, erosional bases and gradational tops, inversely graded laminae with sharp tops, graded rhythmites, cross-, parallel-, and low-angle lamination) are characteristic of distal tempestites and point to a significant role of storm-generated currents in deposition of studied deposits (Leonowicz 2013). If burrows recognized as ?Rosselia really represent this ichnogenera, they fit well such an interpretation, as this trace fossil is characteristic of settings in which rapid storm sedimentation occurs (Nara 2002; Netto et al. 2014). In strongly bioturbated mudstones most of the sedimentary structures are obliterated; however, the presence of relict lamination, common erosion surfaces and minor scours suggest a similar storm influence on deposition (Leonowicz 2015).

A moderate to high bioturbation intensity and low to moderate diversity of the trace fossil association in ichnofabrics 4-5 suggest that they developed under similar oxygenation levels as ichnofabric 2 . In the case of ichnofabric 4 , this interpretation is additionally supported by the occurrence of Taenidium - a trace fossil produced by animals which burrowed within the sediment but did not maintain a connection with the seafloor. Its presence indicates that conditions in interstitial waters were at least dysoxic (Ekdale and Mason 1988). Also, the occurrence of thick Chondrites suggests relatively good oxygenation of the bottom. However, general impoverishment of the trace fossil association points to a negative influence of factors other than oxygenation, including sedimentation rate and the input of benthic food. Ichnofabrics 4 and 5 reflect abundant sediment input and high delivery of nutrients. In ichnofabric $4 \mathrm{a}$, rapid sedimentation resulted in complete reworking of sediment by subsurface trophic generalists, burrowing in the mixed layer and producing indeterminate biodeformational structures. Ichnofabric $4 \mathrm{~b}$ reflects a slower but still increased deposition, enabling colonization of the seafloor by more specialized and deeper-burrowing deposit feeders (Taenidium). In ichnofabric 5, high suspended sediment input impeded development of a diverse trace fossil association, favoring formation of Tasselia-like structures. Rapid event sedimentation of the thick portions of mud might also have led to the formation of alternating laminated and bioturbated beds, representing ichnofabric $1 \mathrm{~b}$. The opposite tendency is reflected by ichnofabric 3 , which records decreased sedimentation rate. Temporal sediment starvation and syndepositional erosion was already postulated in hitherto studies of the ore-bearing clay to explain the origin of horizons of siderite concretions (Witkowska 2012), calcareous hiatus concretions (Zatoń et al. 2011) and intervals with common ammonite occurrence (Leonowicz 2015).

Comparison of the equivalent intervals of the succession from different locations (Częstochowa and Zawiercie areas) shows that the conditions within the basin were not uniform. In the area of Częstochowa, all of the succession studied, assigned to the Upper Bajocian-Upper Bathonian (parkinsoni-retrocostatum zones), is bioturbated and reveals ichnofabrics $2-5$, recording different grades of dysoxic conditions. The succession of the ore-bearing clay from the Zawiercie area (Ogrodzieniec and Blanowice) 
represents the Middle and Upper Bathonian (subcontractus-retrocostatum) zones; thus, it is of the same age as the Gnaszyn and Anna sections from the Częstochowa area. However, it consists mostly of laminated mudstone with ichnofabrics $1 \mathrm{a}$ and $1 \mathrm{~b}$ that reflect oxygen-restricted, suboxic conditions, only temporarily changing to dysoxic. This ichnofabric variability might have resulted from the morphological differentiation of the seafloor, which influenced water circulation and would have been responsible for the oxygenation of the seafloor. One of the possible explanations is an environmental model assuming the occurrence on the seafloor of local hollows with isolated pockets of oxygen-depleted water (Hallam and Bradshaw 1979; Wignall 1991). The differentiation of the seafloor into several swells and depressions has already been postulated for the whole Polish Basin (e.g., Dadlez 1994; Feldman-Olszewska 1997) and its southern part (Barski 1999, 2012; Leonowicz 2013, 2015). On the other hand, deposition of laminated mudstone in more proximal locations (Fig. 4) suggests that the important factor influencing oxygenation of the seafloor might has been increased primary production, triggered by high nutrient input from rivers. This explanation is reinforced by the common occurrence in laminated deposits of sedimentary structures recording the activity of bottom currents (Leonowicz 2013), which contradicts the notion of long-lasting stagnation of the bottom water.

\section{Ichnofabric response to transgressions and regressions of the shoreline}

The comparison of the distribution of ichnofabrics with the T-R cycles, recognized in the succession from Częstochowa (Fig. 11), reveals some correlation, although the biogenic response to the cyclic shoreline fluctuation is not conspicuous. The $\mathrm{T}-\mathrm{R}$ cycles, which range in thickness from 9 to $22 \mathrm{~m}$, were distinguished on the basis of sedimentological features of the mudstone (variation of sand, silt and clay contents, and relicts of sedimentary structuresLeonowicz 2015). Most of these major cycles $\left(\mathrm{TR}_{1}, \mathrm{TR}_{2+3}\right.$, $\mathrm{TR}_{5}$ and $\mathrm{TR}_{6+7}$ ) correlate with cycles distinguished in the succession from central Poland and record relative sealevel changes across the entire Polish Basin. Thinner, minor cycles, which range in thickness from 4 to $10 \mathrm{~m}$, were the result of local events, likely autocyclic shoreline progradation and syndepositional tectonics. The distribution of ichnofabrics has been compared with major as well as minor cycles. The most clear is the correlation of ichnofabric 3 with transgressive pulses (the beginnings of $\mathrm{T}_{4}$ and $\mathrm{T}_{6}$ as well as late phases of $\mathrm{T}_{2}, \mathrm{~T}_{4-2}$, and $\mathrm{T}_{5}$ ). As this ichnofabric records a decreased sedimentation rate, it indicates that some of the transgressions were accompanied by sediment starvation. Such a phenomenon is well known from the concepts of sequence stratigraphy, according to which the condensed section is a characteristic feature of transgressive and high-stand systems tracts (Catuneanu et al. 2011). However, in the deposits studied, condensation is not inherent in every T-R cycle, suggesting that the sediment supply was generally high, also during transgressions. On the other hand, not all condensed intervals, inferred from the common occurrence of ammonites (Leonowicz 2015), coincide with the ichnofabric 3 . This discrepancy may be related to different mechanisms of condensation. The strong reworking of the substrate by deeply burrowing animals requires decreased sediment delivery to the depositional site, whereas concentration of ammonites may result either from the decreased sediment supply or from the recurrent winnowing of mud from the seafloor. Taking into account the relatively shallow-water conditions, the most probable reason of condensation was the bypass of sediment to the deeper parts of the basin (Leonowicz 2015). Resulting slow mud accumulation might lead to development of ichnofabric 3 . However, if the sediment bypass was accompanied by recurrent erosion of the seafloor, the intervals with common ammonites could have been formed.

A clear correlation also exists between ichnofabrics $4 \mathrm{a}$ and $4 \mathrm{~b}$, reflecting high sedimentation rates, and deposits rich in sand and shell debris from the Lower Bathonian zigzag-tenuiplicatus zones $\left(\mathrm{T}_{2}-\mathrm{T}_{4}\right.$, Fig. 11). These deposits record a period of the significant shallowing of the sea and deposition in high-energy conditions, within the range of storm and, temporarily, fair weather waves (Leonowicz 2015). Besides the increased supply of sediment rich in coarse particles, the proximity of the shoreline and expanse of intrabasinal shoals might also account for the high delivery of nutrients, triggering plankton blooms that were an important source of benthic food. The resulting abundance of easy accessible organic particles favored the development of a shallow-burrowing community and formation of ichnofabrics $4 \mathrm{a}$ and $4 \mathrm{~b}$. Of course, the common occurrence of Taenidium and bioturbational structures in deposits rich in sand and shell debris could simply result from the better lithological contrast, improving visibility of trace fossils hardly discernible in lithologically homogenous rocks. However, deposits rich in sand may also reveal ichnofabrics lacking Taenidium and biodeformational structures $(2 \mathrm{~b}$ in the lower and upper parts of the Gnaszyn section and 2a in the upper part of the Anna section, Fig. 5). Instead, they contain common trace fossils of deep tiers (Chondrites, Trichichnus and pyritized burrows type 1), which in turn are rare in ichnofabrics $4 \mathrm{a}$ and $4 \mathrm{~b}$. Thus, it is likely that the appearance of ichnofabric 4 reflects real environmental change, linked to the shift of the depositional site from the offshore to offshore-transition and distal lower shoreface. Similar conditions to these in the Early Bathonian also occurred twice more in the succession: in the Middle 


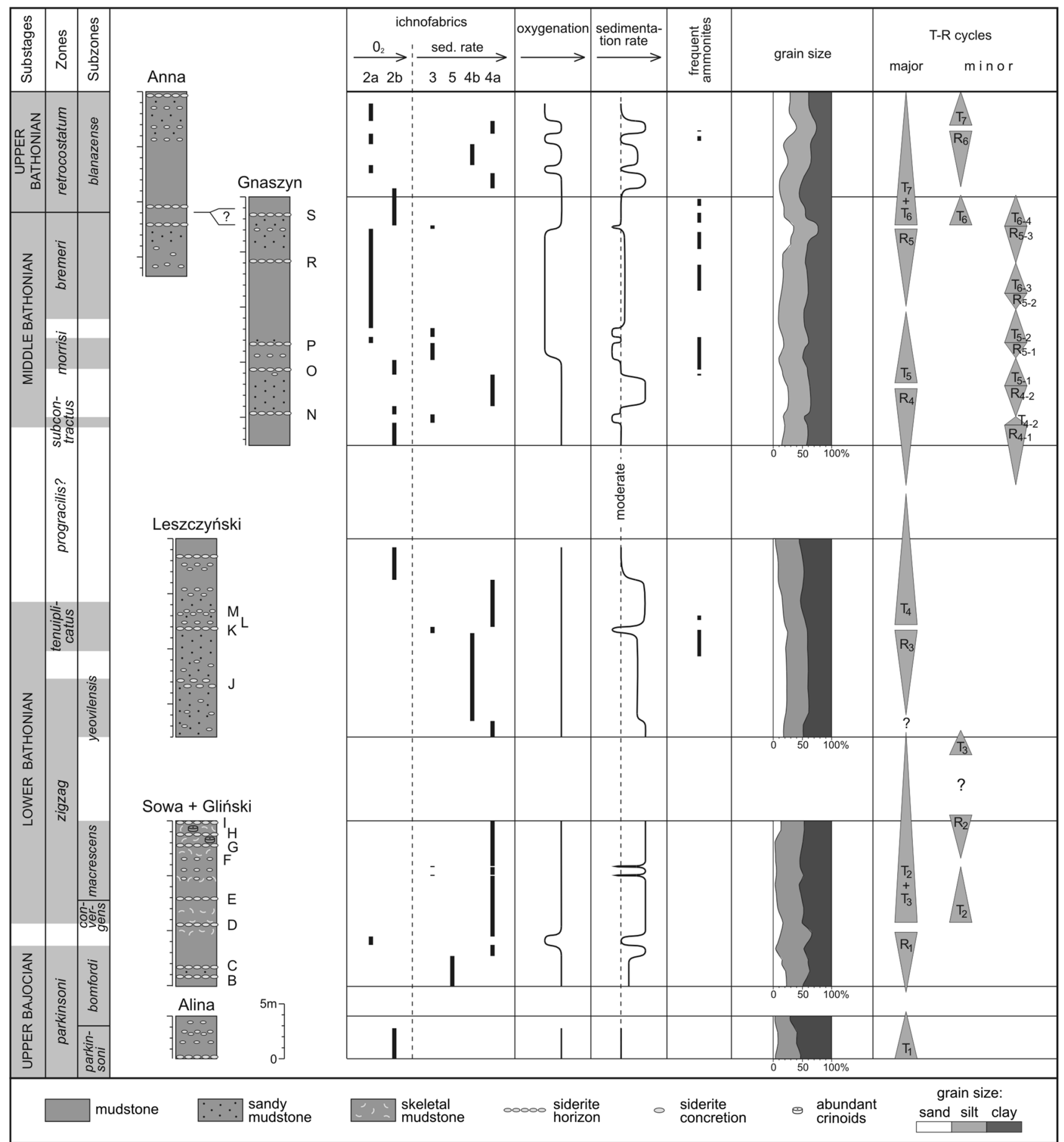

Fig. 11 Sedimentation rate and oxygenation, inferred from ichnofabrics, compared with transgressive-regressive cycles and the grain-size variations in the succession from Częstochowa. T-R cycles and the grain-size diagrams modified after Leonowicz (2015)

Bathonian (subcontractus and/or morrisi chrones) and Late Bathonian (retrocostatum chron), accompanying shorterlasting marine regressions $\left(\mathrm{R}_{4}\right.$ and $\mathrm{R}_{6}$, Fig. 11).

The optimal conditions for benthic life: relatively good oxygenation of the seafloor and moderate sedimentation rate, recorded by ichnofabric $2 b$, usually coincide with transgressions $\left(\mathrm{T}_{1}\right.$, late phase of $\mathrm{T}_{4}$, early phase of $\mathrm{T}_{5}$ and $\mathrm{T}_{6}$, Fig. 11) and early phases of regressions $\left(\mathrm{R}_{4}\right)$, when the depositional site was in a distal location. The worst conditions, resulting in development of ichnofabric $2 \mathrm{a}$, occurred in the Middle Bathonian bremeri chron and were linked to the late phase of $T_{5}$ transgression and $R_{5}$ regression 
(Fig. 11). Leonowicz (2015) suggested that in this time the depositional site reached its most distal position, passing from the bypass zone to the zone where sediment transferred from the nearshore accumulated. The increased supply of mud combined with the higher influx of organic particles, responsible for the oxygen consumption, as well as weakening of the bottom currents which ventilated the seafloor, might have resulted in the decrease of oxygen within the sediment.

Conditions unfavorable for benthic life occurred also in the Late Bajocian (late bomfordi subchron) and were linked to the increased delivery of suspended sediment that hindered development of a benthic community. These specific conditions, recorded by ichnofabric 5 , were related to the significant regression of the shoreline $\left(R_{1}\right.$, Fig. 11) and the transition of the depositional site from a distal to a more proximal location.

\section{Conclusions}

The analysis of the trace fossil associations from Middle Jurassic ore-bearing clay revealed a variability of ichnofabrics, which reflects changes of seafloor oxygenation, sedimentation rate, and benthic food content. These changes partly correlate with $\mathrm{T}-\mathrm{R}$ cycles, previously recognized on the basis of sedimentological analysis.

The trace fossil association consists of ten ichnogenera, including Chondrites, Trichichnus, Palaeophycus, Planolites, Protovirgularia, ?Rosselia, Schaubcylindrichnus, Taenidium, cf. Tasselia and Thalassinoides as well as five types of indeterminate pyritized burrows. It represents the distal expression of Cruziana ichnofacies, which changed in some periods to a more proximal variant of it. Ichnofossils form tiered ichnofabrics, consisting of at least four tiers. Different variants of ichnofabrics reflect changing environmental factors, which restricted development of particular tiers.

Based on the composition of the trace fossil association, bioturbation intensity, and the type of biodeformational structures, eight ichnofabric variants have been distinguished. The sequence of ichnofabrics $1 a-1 b-2 a-2 b$ reflects increasing oxygenation of the bottom sediment. Ichnofabrics $4 \mathrm{a}, 4 \mathrm{~b}$, and 5 record high rates of deposition, whereas ichnofabric 3 reflects sediment starvation. Distribution of ichnofabrics in the succession shows that the bottom-water conditions varied laterally within the basin and changed with time. This variability is undetectable based on geochemical indices that reinforces the importance of ichnofabric analysis in environmental studies of mudstone.

A comparison of the distribution of ichnofabrics with $\mathrm{T}-\mathrm{R}$ cycles showed limited correlation. The shallowest and the most proximal location of the depositional site is recorded by ichnofabrics $4 \mathrm{a}$ and $4 \mathrm{~b}$. The most distal position correlates with the occurrence of ichnofabrics $2 \mathrm{a}$, reflecting poor oxygenation of the seafloor. Transgressions were linked to the improvement of seafloor oxygenation (ichnofabric 2b) and temporary sediment starvation (ichnofabric 3), related most probably to sediment bypass. It seems that ichnofabrics reflect well the major changes of basin depth and distance from the shoreline but do not record minor fluctuations, which can be deduced from other sedimentological features.

Acknowledgments The authoress would like to thank A. Uchman, Jagiellonian University, for his kind help, discussions, and valuable advice in trace fossil determination and interpretation. I also thank M. Nara, E. Olivero. and A. Wetzel for consultation in the trace fossil determination. The paper benefited greatly from careful reviews by G.S. Bressan and F.J. Rodríguez-Tovar, whose corrections and comments substantially helped me to revise the manuscript. I also thank M. Tucker, the journal editor, for kind help with editorial matters and language corrections. The managements of brickyards: "Alina", "Sowa", CEGBUD Gliński, Leszczyński-Wytrzymały, "Anna", Wienerberger Gnaszyn in Częstochowa as well as "Keram" in Ogrodzieniec and brickyard in Blanowice are thanked for providing access to their workings. This research was supported by funds of the Institute of Geology, University of Warsaw.

Open Access This article is distributed under the terms of the Creative Commons Attribution 4.0 International License (http://creativecommons.org/licenses/by/4.0/), which permits unrestricted use, distribution, and reproduction in any medium, provided you give appropriate credit to the original author(s) and the source, provide a link to the Creative Commons license, and indicate if changes were made.

\section{References}

Barski M (1999) Dinocyst stratigraphy of the Jurassic black clays from Holy Cross Mts area (Central Poland) (in Polish with English summary). Prz Geol 47:718-722

Barski M (2012) Dinoflagellate cysts from neptunian dykes in the Middle Jurassic of Poland-a stratigraphical approach. Rev Palaeobot Palynol 169:38-47

Barski M, Dembicz K, Praszkier T (2004) Biostratigraphy and the Mid-Jurassic environment from the Ogrodzieniec quarry (in Polish with English summary). Tomy Juraj 2:61-68

Brett CE (1983) Sedimentology, facies and depositional environments of the Rochester Shale (Silurian; Wenlokian) in western New York and Ontario. J Sediment Petrol 53:947-971

Bromley R (1990) Trace fossils. Biology and taphonomy. Unwin Hyman, London

Bromley RG, Ekdale AA (1984) Chondrites: a trace fossil indicator of anoxia in sediments. Science 224:872-874

Bromley RG, Ekdale AA (1986) Composite ichnofabrics and tiering of burrows. Geol Mag 123:59-65

Buatois LA, Mángano MG (2011) Ichnology. Organism-substrate interactions in space and time. Cambridge University Press, Cambridge

Catuneanu O, Galloway WE, Kendall CGStC, Miall AD, Posamentier HW, Strasser A, Tucker ME (2011) Sequence stratigraphy: methodology and nomenclature. Newsl Stratigr 44:173-245

Chamberlain CK (1975) Trace fossils in DSDP cores of the Pacific. J Paleontol 49:1074-1096 
Cosson N, Sibuet M, Galeron J (1997) Community structure and spatial heterogeneity of the deep-sea macrofauna at three contrasting stations in the tropical northeast Atlantic. Deep Sea Res I 44:247-269

D'Alessandro A, Bromley RG (1987) Meniscate trace fossils and the Muensteria-Taenidium problem. Palaeontology 30:743-763

Dadlez R (1989) Epicontinental Permian and Mesozoic basins in Poland (in Polish with English summary). Kwart Geol 33:175-198

Dadlez R (1994) Strike-slip movements in the Polish Lowlands. Geol Q 38:307-318

Dadlez R, Marek S, Pokorski J (eds) (2000) Geological map of Poland without Cainozoic deposits, 1:1000000. Państwowy Instytut Geologiczny, Warszawa

Dayczak-Calikowska K (1997) Middle Jurassic: Sedimentation, palaeogeography and palaeotectonics (in Polish). In: Marek S, Pajchlowa M (eds) Epicontinental Permian and Mesozoic in Poland. Pr Państw Inst Geol 153, pp 269-282

Droser ML, Bottjer DJ (1986) A semiquantitative field classification of ichnofabric. J Sediment Res 56:558-559

Ekdale AA, Mason TR (1988) Characteristic trace-fossil associations in oxygen-poor sedimentary environments. Geology 16:720-723

Feldman-Olszewska A (1997) Depositional architecture of the Polish epicontinental Middle Jurassic basin. Geol Q 41:491-508

Feldman-Olszewska A (1998) Palaeogeographical map of Middle Bathonian bremeri zone. In: Dadlez R, Marek S, Pokorski J (eds) Palaeogeographical atlas of the epicontinental Permian and Mesozoic in Poland. Państwowy Instytut Geologiczny, Warszawa, pl. 45

Frey RW, Curran HA, Pemberton SG (1984) Tracemaking activities of crabs and their environmental significance: the ichnogenus Psilonichnus. J Paleontol 58:333-350

Fu S (1991) Funktion, Verhalten und Einteilung fucoider und lophoctenoider Lebensspuren. Courier Forschung Institut Senckenberg 135:1-79

Gedl P, Boczarowski A, Kaim A, Kędzierski M, Leonowicz P, Smoleń J, Szczepanik P, Witkowska M (2006a) Field trip B1-biostratigraphical framework from Bajocian to Oxfordian. Stop B1.5Sowa's and Gliński's clay pits (uppermost Bajocian-lowermost Bathonian). Lithology, fossil assemblages and palaeoenvironment. In: Wierzbowski A et al (eds) Jurassic of Poland and adjacent Slovakian Carpathians. Field trip guidebook. 7th international congress on the Jurassic System, Kraków, Poland, 6-18 September 2006, pp 151-152

Gedl P, Boczarowski A, Kaim A, Kędzierski M, Leonowicz P, Smoleń J, Szczepanik P, Witkowska M (2006b) Field trip B1-biostratigraphical framework from Bajocian to Oxfordian. Stop B1.6Leszczyński's clay pit (Lower Bathonian). Lithology, fossil assemblages and palaeoenvironment. In: Wierzbowski A et al (eds) Jurassic of Poland and adjacent Slovakian Carpathians. Field trip guidebook. 7th international congress on the Jurassic System, Kraków, Poland, 6-18 September 2006, pp 153-154

Gedl P, Boczarowski A, Dudek T, Kaim A, Kędzierski M, Leonowicz P, Smoleń J, Szczepanik P, Witkowska M, Ziaja J (2006c) Field trip B1-biostratigraphical framework from Bajocian to Oxfordian. Stop B1.7-Gnaszyn clay pit (Middle Bathonian-lowermost Upper Bathonian). Lithology, fossil assemblages and palaeoenvironment. In: Wierzbowski A et al (eds) Jurassic of Poland and adjacent Slovakian Carpathians. Field trip guidebook. 7th international congress on the Jurassic System, Kraków, Poland, 6-18 September 2006, pp 155-156

Gedl P, Kaim A, Leonowicz P, Boczarowski A, Dudek T, Kędzierski M, Rees J, Smoleń J, Szczepanik P, Sztajner P, Witkowska M, Ziaja J (2012) Palaeoenvironmental reconstruction of Bathonian (Middle Jurassic) ore-bearing clays at Gnaszyn, Kraków-Silesia Homocline, Poland. Acta Geol Polon 62:463-484

Hallam A, Bradshaw MJ (1979) Bituminous shales and oolitic ironstones as indicators of transgressions and regressions. J Geol Soc 136:157-164
Immenhauser A (2009) Estimating palaeo-water depth from the physical rock record. Earth Sci Rev 96:107-139

Kaim A, Sztajner P (2012) Faunal dynamics of bivalves and scaphopods in the Bathonian (Middle Jurassic) ore-bearing clays at Gnaszyn, Kraków-Silesia Homocline, Poland. Acta Geol Polon 62:381-395

Kopik J (1997) Middle Jurassic: formal and informal stratigraphic units-Polish Jura (in Polish). In: Marek S, Pajchlowa M (eds) Epicontinental Permian and Mesozoic in Poland. Pr Państw Inst Geol 15, pp 263-264

Kopik J (1998) Lower and Middle Jurassic of the north-eastern margin of the Upper Silesian Coal Basin (in Polish with English summary). Biul Państw Inst Geol 378:67-129

Leonowicz P (2012) Sedimentology and ichnology of Bathonian (Middle Jurassic) ore-bearing clays at Gnaszyn, Kraków-Silesia Homocline, Poland. Acta Geol Polon 62:281-296

Leonowicz P (2013) The significance of mudstone fabric combined with palaeoecological evidence in determining sedimentary processes-an example from the Middle Jurassic of southern Poland. Geol Q 57:243-260

Leonowicz P (2015) Storm-influenced deposition and cyclicity in a shallow-marine mudstone succession-example from the Middle Jurassic ore-bearing clays of the Polish Jura (southern Poland). Geol Q. doi:10.7306/gq.1221

Lewandowski J (1986) Geological sketch without Cainozoic deposits, 1:100000. In: Bardziński W et al (eds) Detailed Geological Map of Poland Report, Częstochowa sheet, 1:50000. Wydawnictwa Geologiczne, Warszawa

Löwemark L, Nara M (2010) Morphology, ethology and taxonomy of the ichnogenus Schaubcylindrichnus: notes for clarification. Palaeogeogr Palaeoclimatol Palaeoecol 297:184-187

Löwemark L, Nara M (2013) Morphological variability of the trace fossil Schaubcylindrichnus coronus as a response to environmental forcing. Palaeontol Electron 16(1):5A

MacEachern JA, Bann KL, Pemberton SG, Gingras MK (2007) The ichnofacies paradigm: high-resolution paleoenvironmental interpretation of the rock record. In: MacEachern JA, Bann KL, Pemberton SG, Gingras MK (eds) Applied ichnology. Soc Sediment Geol Short Course Notes 52, pp 27-64

Martin KD (2004) A re-evaluation of the relationship between trace fossils and dysoxia. In: McIlroy D (ed) The application of ichnology to palaeoenvironmental and stratigraphic analysis. Geol Soc Spec Publ 228:141-156

Marynowski L, Zatoń M, Simoneit BRT, Otto A, Jędrysek MO, Grelowski C, Kurkiewicz S (2007) Compositions, sources and depositional environments of organic matter from the Middle Jurassic clays of Poland. Appl Geochem 22:2456-2485

Matyja BA, Wierzbowski A (2000) Ammonites and stratigraphy of the uppermost Bajocian and Lower Bathonian between Częstochowa and Wieluń, Central Poland. Acta Geol Polon 50:191-209

Matyja BA, Wierzbowski A (2003) Ammonite biostratigraphy of the Ore-Bearing Częstochowa Clay Formation (uppermost Bajocian-Upper Bathonian) from exposures in Częstochowa (in Polish). Tomy Juraj 1:3-6

Matyja BA, Wierzbowski A (2006a) European platform. Introduction. Middle and Upper Jurassic. In: Wierzbowski A et al (eds) Jurassic of Poland and adjacent Slovakian Carpathians. Field trip guidebook. 7th international congress on the Jurassic System, Kraków, Poland, 6-18 September 2006, pp 130-131

Matyja BA, Wierzbowski A (2006b) Field trip B1-biostratigraphical framework from Bajocian to Oxfordian. Stop B1.5-Sowa's and Gliński's clay pits (uppermost Bajocian-lowermost Bathonian). Ammonite biostratigraphy. In: Wierzbowski A et al (eds) Jurassic of Poland and adjacent Slovakian Carpathians. Field trip guidebook. 7th international congress on the Jurassic System, Kraków, Poland, 6-18 September 2006, pp 149-151 
McBride EF, Picard MD (1991) Facies implications of Trichichnus and Chondrites in turbidites and hemipelagites, Marnoso-arenacea Formation (Miocene), Northern Apennines, Italy. Palaios 6:281-290

McIlroy D (2007) Lateral variability in shallow-marine ichnofabrics: implications for the ichnofabric analysis method. J Geol Soc 164:359-369

Merta T, Drewniak A (1998) Lithology and depositional environment of the Bathonian clays. In: Poulsen NE et al (eds) MellemØvre Jura i Polen. EEP-1995 projekt: Det polske Mellem-Øvre Epikratoniske Bassin, Stratigrafi, Facies og Bassin Historie. Program Østeuropa. Danmarks og Grønlands Geologiske Undersøgelse Rapport 1998/14, pp 25-41

Nara M (1995) Rosselia socialis: a dwelling structure of a probable terebellid polychaete. Lethaia 28:171-178

Nara M (2002) Crowded Rosselia socialis in Pleistocene inner shelf deposits: benthic paleoecology during rapid sea-level rise. Palaios 17:268-276

Nara M (2006) Reappraisal of Schaubcylindrichnus: a probable dwelling/feeding structure of a solitary funnel feeder. Palaeogeogr Palaeoclimatol Palaeoecol 240:439-452

Netto RG, Tognoli FMW, Nara M (2014) Crowded Rosselia ichnofabric in the Early Devonian of Brazil: an example of strategic behaviour. Palaeogeogr Palaeoclimatol Palaeoecol 395:107-113

Olivero EB, López Cabrera MI (2010) Tasselia ordamensis: a biogenic structure of probable deposit-feeding and gardening maldanid polychaetes. Palaeogeogr Palaeoclimatol Palaeoecol 292:336-348

Pemberton SG, Frey RW (1982) Trace fossil nomenclature and the Planolites-Palaeophycus dilemma. J Paleontol 56:843-881

Pemberton SG, Spila M, Pulham AJ, Saunders T, MacEachern JA, Robbins D, Sinclair IK (2001) Ichnology and sedimentology of shallow to marginal marine systems: Ben Nevis and Avalon Reservoirs, Jeanne d'Arc Basin. Geol Assoc Can Short Course Notes $15: 1-343$

Pieńkowski G (1985) Early Liassic trace fossil assemblages from the Holy Cross Mountains, Poland: their distribution in continental and marginal marine environments. In: Curran HA (ed) Biogenic structures: their use in interpreting depositional environments. Soc Econ Paleontol Mineral Spec Publ 35:37-51

Pieńkowski G, Schudack ME (co-ordinators), Bosák P, Enay R, Feldman-Olszewska A, Golonka J, Gutowski J, Herngreen GFW, Jordan P, Krobicki M, Lathuiliere B, Leinfelder RR, Michalík J, Mönnig E, Noe-Nygaard N, Pálfy J, Pint A, Rasser MW, Reisdorf AG, Schmid DU, Schweigert G, Surlyk F, Wetzel A, Wong TE (2008) Jurassic. In: McCann T (ed) The geology of Central Europe. Mesozoic and Cenozoic, vol 2. Geological Society of London, pp 823-922

Quijón PA, Kelly MC, Snelgrove PVR (2008) The role of sinking phytodetritus in structuring shallow-water benthic communities. J Exp Mar Biol Ecol 366:134-145

Romero-Wetzel MB (1987) Sipunculans as inhabitants of very deep, narrow burrows in deep-sea sediments. Mar Biol 96:87-91

Savrda CE, Bottjer DJ (1989) Trace-fossil model for reconstructing oxygenation histories of ancient marine bottom waters: application to Upper Cretaceous Niobrara Formation, Colorado. Palaeogeogr Palaeoclimatol Palaeoecol 74:49-74

Savrda CE, Bottjer DJ (1991) Oxygen-related biofacies in marine strata: an overview and update. Geol Soc Spec Publ 58:201-219
Savrda CE, Bottjer DJ, Gorsline DS (1984) Development of a comprehensive oxygen-deficient marine biofacies model: evidence from Santa Monica, San Pedro and Santa Barbara Basins, California Continental Borderland. Am Assoc Petrol Geol Bull 68:1179-1192

Schieber J (2003) Simple gifts and buried treasures-implications of finding bioturbation and erosion surfaces in black shales. Sediment Rec 1:4-8

Seilacher A, Seilacher E (1994) Bivalvian trace fossils: a lesson from actuopaleontology. Cour Forsch Senckenberg 169:5-15

Smoleń J (2006) Palaeoenvironmental significance of the foraminiferal assemblages from the Middle Jurassic deposits of the Częstochowa area. Vol Jurass 4:136-137

Smoleń J (2012) Faunal dynamics of foraminiferal assemblages in the Bathonian (Middle Jurassic) ore-bearing clays at Gnaszyn, Kraków-Silesia Homocline, Poland. Acta Geol Polon 62:403-419

Szczepanik P, Witkowska M, Sawłowicz Z (2007) Geochemistry of Middle Jurassic mudstones (Kraków-Częstochowa area, southern Poland): interpretation of the depositional redox conditions. Geol Q 51:57-66

Taylor A, Goldring R, Gowland S (2003) Analysis and application of ichnofabrics. Earth Sci Rev 60:227-259

Tufail A, Meadows PS, McLaughlin P (1989) Meso- and microscale heterogeneity in benthic community structure and the sedimentary environment on an intertidal muddy-sand beach. Sci Mar 53:319-327

Wetzel A (1991) Ecologic interpretation of deep-sea trace fossil communities. Palaeogeogr Palaeoclimatol Palaeoecol 85:47-69

Wetzel A (2008) Recent bioturbation in the deep South China Sea: a uniformitarian ichnologic approach. Palaios 23:601-615

Wetzel A, Bromley R (1996) The ichnotaxon Tasselia ordamensis and its junior synonym Caudichnus annulatus. J Paleontol 70:523-526

Wetzel A, Uchman A (1998) Biogenic sedimentary structures in mudstones-an overview. In: Schieber J, Zimmerle W, Sethi PS (eds) Shales and Mudstones I. E. Schweizerbart'sche Verlagsbuchhandlung, Stuttgart, pp 351-369

Wignall PB (1991) Model for transgressive black shales? Geology 19:167-170

Witkowska M (2012) Palaeoenvironmental significance of iron carbonate concretions from the Bathonian (Middle Jurassic) orebearing clays at Gnaszyn, Krakow-Silesia Homocline, Poland. Acta Geol Polon 62:307-324

Zatoń M (2007) Amonity z iłów rudonośnych (bajos-baton) Jury Polskiej. Unpublished PhD thesis, University of Silesia, Sosnowiec

Zatoń M, Marynowski L, Szczepanik P, Bond DPG, Wignall PB (2009) Redox conditions during sedimentation of the Middle Jurassic (Upper Bajocian-Bathonian) clays of the Polish Jura (south-central Poland). Facies 55:103-114

Zatoń M, Machocka S, Wilson MA, Marynowski L, Taylor PD (2011) Origin and paleoecology of Middle Jurassic hiatus concretions from Poland. Facies 57:275-300

Zatoń M, Kremer B, Marynowski L, Wilson MA, Krawczyński W (2012) Middle Jurassic (Bathonian) encrusted oncoids from the Polish Jura, southern Poland. Facies 58:57-77

Ziegler PA (1990) Geological atlas of western and central Europe. Shell Internationale Petroleum Maatschappij BV, The Hague 